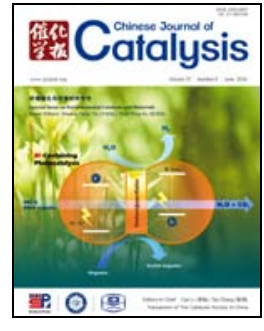

Review (Special Issue on Environmental Catalysis and Materials)

\title{
Bicarbonate activation of hydrogen peroxide: A new emerging technology for wastewater treatment
}

\author{
Ali Jawad, Zhuqi Chen, Guochuan Yin* \\ Hubei Key Laboratory of Material Chemistry and Service Failure, School of Chemistry and Chemical Engineering, Huazhong University of Science and \\ Technology, Wuhan 430074, Hubei, China
}

A R T I C L E I N F 0

Article history:

Received 29 February 2016

Accepted 31 March 2016

Published 5 June 2016

\section{Keywords:}

Wastewater treatment

Bicarbonate activated hydrogen

peroxide

Catalyst leaching

Pollutant degradation

Catalytic oxidation

\begin{abstract}
A B S T R A C T
The serious limitations of available technologies for decontamination of wastewater have compelled researchers to search for alternative solutions. Catalytic treatment with hydrogen peroxide, which appears to be one of the most efficient treatment systems, is able to degrade various organics with the help of powerful $\bullet \mathrm{OH}$ radicals. This review focuses on recent progress in the use of bicarbonate activated hydrogen peroxide for wastewater treatment. The introduction of bicarbonate to pollutant treatment has led to appreciable improvements, not only in process efficiency, but also in process stability. This review describes in detail the applications of this process in homogeneous and heterogeneous systems. The enhanced degradation, limited or lack of leaching during heterogeneous degradation, and prolonged catalysts stability during degradation are salient features of this system. This review provides readers with new knowledge regarding bicarbonate, including the fact that it does not always harm pollutant degradation, and can significantly benefit degradation under some conditions.
\end{abstract}

(C) 2016, Dalian Institute of Chemical Physics, Chinese Academy of Sciences. Published by Elsevier B.V. All rights reserved.

\section{Introduction}

The discharge of untreated water into aquatic natural resources has resulted in widespread contamination by various pollutants, including organic dyes, endocrine-disrupting chemicals, agrochemicals, halogenated aliphatic and aromatic compounds, and sulfur and nitrogen containing organic compounds [1-6]. The increasing accumulation of these toxins requires efficient, practical and cost effective technologies for treatment of wastewater. Traditional treatment systems such as physico-chemical (flocculation, chlorination and ozonation), adsorption or thermal treatment generally require post-treatments to achieve complete de-contamination [7-8]. However, these treatments are not efficient, especially in the case of highly polluted water, and some of these methods result in the production of even more toxic compounds. Alternatively, advanced oxidation processes (AOPs) are suitable for efficient removal of pollutants in wastewater. With versatile oxidants, these AOPs can generate different reactive oxygen species (ROS) such as hydroxyl radicals $(\bullet \mathrm{OH})$, singlet oxygen $\left({ }^{1} \mathrm{O}_{2}\right)$ and superoxide anion $\left(\bullet \mathrm{O}_{2}\right)$ for complete removal of toxic pollutants [9-11]. It is well known that use of ozone or molecular oxygen as an oxidant is subject to gas/liquid solubility problems, which result in high energy consumption, while treatment with $\mathrm{H}_{2} \mathrm{O}_{2}$ appears to be a feasible protocol among AOPs [12]. The lack of a gas-liquid boundary makes use of $\mathrm{H}_{2} \mathrm{O}_{2}$ as an oxidant greatly attractive, and the degradation can be conducted under mild conditions, demonstrating its advantages when compared with wet air oxidation (WAOs). In previous studies, Fenton's reagent $\left(\mathrm{Fe}^{2+}\right)$ or other transition

\footnotetext{
* Corresponding author. Tel: +86-27-87543032; Fax: +86-27-87543632; E-mail: gyin@hust.edu.cn This work was supported by the National Natural Science Foundation of China (21273086). 
metals such as $\mathrm{Fe}^{3+}, \mathrm{Cu}^{2+}, \mathrm{Mn}^{2+}$ and $\mathrm{Co}^{2+}$ have been widely applied as homogeneous catalysts during the degradation of pollutants [13-15]. However, the limited range of $\mathrm{pH}(2-4)$ and the recovery of homogeneous catalyst are serious issues in their practical application. The strategies of immobilization of transition metals over different supports have been extensively explored to minimize the catalyst loss and heavy metal pollution [16-21]. However, during advanced oxidation treatment of wastewater, the solution pH may gradually drop, encouraging catalyst leaching and deactivation. As shown in Table 1, the solution pHs of different systems clearly demonstrate their influence on catalyst leaching [22-29]. Therefore, a constant $\mathrm{pH}$ is important for process stability and reduced environmental damage during wastewater treatment.

Bicarbonate is highly soluble in water, relatively non-toxic and widely distributed in nature (50-200 ppm in natural water), as well as in biological systems (14.7-25 mmol/L), and exists in different forms constituting the main biological buffer Eq. (1) [30]. Normally, bicarbonate is more soluble at $\mathrm{pH}$ 7.0-9.0, while at above or below this range it changes to less soluble $\mathrm{Na}_{2} \mathrm{CO}_{3}$ or carbonic acid, respectively.

$$
\begin{gathered}
\mathrm{CO}_{2} \leftrightarrow \mathrm{CO}_{2}+\mathrm{H}_{2} \mathrm{O} \leftrightarrow \mathrm{H}_{2} \mathrm{CO}_{3} \leftrightarrow \mathrm{HCO}_{3}+\mathrm{H}^{+} \\
\bullet \mathrm{OH}+\mathrm{HCO}_{3}-\rightarrow \mathrm{H}_{2} \mathrm{O}+\bullet \mathrm{CO}_{3}^{-} \\
\mathrm{H}_{2} \mathrm{O}_{2}+\mathrm{HCO}_{3}-\rightarrow \mathrm{H}_{2} \mathrm{O}+\mathrm{HCO}_{4}^{-}
\end{gathered}
$$

Notably, carbonate/bicarbonate ions are believed to change the redox properties of metals ions in ocean water, providing an opportunity to organisms to selectively take up metals [31]. Moreover, bicarbonate is reportedly involved in the structure and function of water oxidizing complex (a part of the photosystem II protein complex that oxidizes water to dioxygen), and increases the rate of electron transfer from $\mathrm{Mn}^{2+}$ to apo-PS II by forming ternary complex [31-33]. Apart from numerous functions in biological systems, the role of bicarbonate activation has also been studied extensively in organic reactions [34-39]. However, the application of this reagent in combination with certain AOPs for wastewater treatment is a newly emerging topic. In fact, the roles of bicarbonate in AOPs during wastewater treatment are controversial among researchers because enough data are available to support as the view of its promoting or scavenging AOPs during wastewater degradation. Nevertheless, bicarbonate still possesses some encouraging properties for its application in wastewater. For example, its buffer capacity (pH 8.0-9.0), low cost, high solubility and particularly its capability to activate $\mathrm{H}_{2} \mathrm{O}_{2}$ are attractive properties for developing a sustainable treatment system [30,34-39]. As in AOPs, various reactive oxygen species (ROS) such as $\bullet \mathrm{OH}$, $\cdot \mathrm{O}_{2}{ }^{-}$and ${ }^{1} \mathrm{O}_{2}$ mainly controlled the degradation of pollutants. The generation of even more reactive species $\left(\mathrm{HCO}_{4}^{-}, \cdot \mathrm{CO}_{3}^{-}\right.$, $\mathrm{HCO}_{3} \bullet$ ) along with the aforementioned ROS was proposed in bicarbonate activated hydrogen peroxide (BAP) systems in different studies [40-45]. Although the $\bullet \mathrm{CO}_{3}-$ radical produced through (Eq. 2) is less reactive $\left(\mathrm{E}_{\mathrm{o}}+1.78 \mathrm{~V}, \mathrm{pH} 7\right)$ than $\bullet \mathrm{OH}$ radical $\left(E_{\mathrm{o}}+2.3 \mathrm{~V}, \mathrm{pH} 7\right)$, its occurrence in high concentration (10-13-10-15 $\mathrm{mol} / \mathrm{L})$ and long lifetime in reaction medium may provide it with sufficient opportunity for pollutant degradation [46]. Moreover, $\bullet \mathrm{CO}_{3}-$ radical is a very strong single electron oxidant that can react by both electron transfer and hydrogen abstraction. For example, it was reported that $\bullet \mathrm{CO}_{3}{ }^{-}$radical can react rapidly with organic pesticides, sulfur containing compounds and aromatic compounds $[39,46]$. Similarly, peroxymonocarbonate $\left(\mathrm{HCO}_{4}^{-}\right)$produced through Eq. (3) is a well-known two-electron oxidant that has been investigated since its discovery in 1984 [47]. $\mathrm{HCO}_{4}{ }^{-}$anion is considered to be more reactive than $\mathrm{H}_{2} \mathrm{O}_{2}$ (100-500 times) in different reactions depending on the substrate [47]. In view of various active oxidizing reagents generated from BAP systems and their important roles in other fields, the addition of the BAP system to wastewater treatment is attractive. Although this is a newly emerging method and many issues still need to be addressed, summarizing its progress will help researchers to explore new technologies for the future development of a sustainable and green solution for wastewater treatment.

\section{BAP as a newly emerging wastewater treatment system}

Different attempts have been made to solve the serious issues occurring during pollutant degradation when treating wastewater [48-57]. However, the challenges associated with these available technologies still require the development of new efficient, cost effective and sustainable treatment systems. In the recently developed BAP system, the operation conditions are generally mild, with a $\mathrm{pH}$ around neutral or weakly alkaline, unlike the strongly alkaline conditions commonly used during peroxide bleaching [58]. Similarly, the components of the BAP system are economical, environmentally friendly and have the potential for treatment of chemical warfare agents such as HD [bis(2-chloroethyl) sulfide], GB (pinacolyl methylphosphono-

\begin{tabular}{|c|c|c|c|c|c|}
\hline Catalyst & Conversion (\%) & $\mathrm{pH}$ & Conditions & Leaching & Ref. \\
\hline $\mathrm{CuO} / \mathrm{C}$ & 100 & Not controlled & Phenol $1 \mathrm{~g} / \mathrm{L}, \mathrm{H}_{2} \mathrm{O}_{2} 0.1 \mathrm{~mol} / \mathrm{L}$, catalyst $2 \mathrm{~g} / \mathrm{L}, 180 \mathrm{~min}, 80^{\circ} \mathrm{C}$ & Not reported & [22] \\
\hline $\mathrm{Cu} / \mathrm{ZSM}-5$ & 36 & Not controlled & Phenol $0.01 \mathrm{~mol} / \mathrm{L}, \mathrm{H}_{2} \mathrm{O}_{2} 0.1 \mathrm{~mol}$, catalyst $0.1 \mathrm{~g} / \mathrm{L}, 180 \mathrm{~min}, 50^{\circ} \mathrm{C}$ & $3.2 \%$ & [23] \\
\hline $\mathrm{Cu} / \alpha-\mathrm{Al}_{2} \mathrm{O}_{3}$ & 100 & Not controlled & Phenol $0.01 \mathrm{~mol}, \mathrm{H}_{2} \mathrm{O}_{2} 0.1 \mathrm{~mol}$, catalyst $5 \mathrm{~g} / \mathrm{L}, 180 \mathrm{~min}, 90^{\circ} \mathrm{C}$ & $65 \%$ & [24] \\
\hline Al-Cu modified clays & Not reported & Buffered pH 4-5 & Phenol $0.05 \mathrm{mmol} / \mathrm{L}, \mathrm{H}_{2} \mathrm{O}_{2}, 0.5-0.1 \mathrm{~N}$, catalyst $0.5 \mathrm{~g}, 20 \mathrm{~h}, 20^{\circ} \mathrm{C}$ & $2 \mathrm{ppm}$ & [25] \\
\hline Cu-silicate & 49.2 & Not controlled & Phenol $1 \mathrm{~g} / \mathrm{L}, \mathrm{H}_{2} \mathrm{O}_{2}, 0.1 \mathrm{~mol}$, catalyst $0.6 \mathrm{~g} / \mathrm{L}, 120 \mathrm{~min}, 70^{\circ} \mathrm{C}$ & $63.5 \%$ & [26] \\
\hline $\mathrm{Cu}-\mathrm{Y}-5$ & 50 & Not controlled & Phenol $0.01 \mathrm{~mol}, \mathrm{H}_{2} \mathrm{O}_{2}, 0.03 \mathrm{~mol}$, catalyst $0.1 \mathrm{~g} / \mathrm{L}, 180 \mathrm{~min}, 50^{\circ} \mathrm{C}$ & $4.80 \%$ & [27] \\
\hline Co-diatomite & 100 & $\begin{array}{l}\text { pH } 8.2 \text { buffered with } \\
\text { bicarbonate }\end{array}$ & $\begin{array}{c}\mathrm{MB} 60 \mathrm{mmol} / \mathrm{L}, \mathrm{H}_{2} \mathrm{O}_{2} 80 \mathrm{mmol} / \mathrm{L}, \mathrm{NaHCO}_{3} 50 \mathrm{mmol} / \mathrm{L} \text {, catalyst } \\
11.4 \mathrm{~g} \text {, treatment time } 180 \mathrm{~h}\end{array}$ & $0.20 \mathrm{ppm}$ & [29] \\
\hline Co/RM-T & 100 & Not controlled & Catalyst $0.2 \mathrm{~g}$, oxone $1 \mathrm{~g}$, phenol $25 \mathrm{ppm}, 25^{\circ} \mathrm{C}, 90 \mathrm{~min}$ & $7.6 \%$ & [28] \\
\hline Co/RM-NT & 100 & Not controlled & Catalyst $0.2 \mathrm{~g}$, oxone $1 \mathrm{~g}$, phenol $25 \mathrm{ppm}, 25^{\circ} \mathrm{C}, 90 \mathrm{~min}$ & $7.4 \%$ & [28] \\
\hline
\end{tabular}

Table 1

Leaching of supported catalysts during treatment of organic pollutants. 
fluoridate), and VX [O-ethyl S-(2-diisopropylamino)ethyl methylphosphonothioate], indicating its potential for use as a broad-spectrum decontamination solution [59]. In particular, these merits of the BAP system are common challenges associated with other AOPs for wastewater [60-62]. To date, the BAP system has been investigated for use in treatment of a wide range of organic contaminants. These techniques have used either direct BAP systems or those that are activated with homogeneous or heterogeneous catalysts. These investigations are reviewed here, as well as studies introduced from other fields.

\subsection{Metal free $\mathrm{BAP}$ system $\left(\mathrm{HCO}_{3}-/ \mathrm{H}_{2} \mathrm{O}_{2}\right)$ for degradation of organic pollutants}

Generally, AOPs are considered one of the most efficient systems for treatment of wastewater, and the development of sustainable AOPs requires inexpensive oxidants that are easily soluble under neutral conditions. Among different oxidants, $\mathrm{H}_{2} \mathrm{O}_{2}$ is most commonly applied in AOPs because of its eco-friendly nature. However, the poor leaving tendency of the hydroxide ion from $\mathrm{H}_{2} \mathrm{O}_{2}$ makes it less reactive and thus always requires activation. The activation of $\mathrm{H}_{2} \mathrm{O}_{2}$ can be achieved by different methods such as transition metal salts or complexes [34], carboxylic acid (peroxyacid) [63], acetonitrile (peroxycarboxymidic acid) [64], urea (peroxyo urea) [65], or sodium perborate and sodium percarbonate in strong basic medium [66]. These systems all offer one or more broad disadvantages, such as toxicity associated with metals, organic byproducts, severe $\mathrm{pH}$ conditions and other problems created by the oxidative decomposition of organic ligands. The BAP system was first introduced by Drago et al. [67] and Yao et al. [34], and has since been used extensively in many organic reactions.

In view of the naturally abundant availability, high solubility, less toxic nature and its activation ability for $\mathrm{H}_{2} \mathrm{O}_{2}$, a metal free system $\left(\mathrm{HCO}_{3}-/ \mathrm{H}_{2} \mathrm{O}_{2}\right)$ was introduced by $\mathrm{Xu}$ et al. [68] for degradation of various organic compounds, including methyl blue (MB), methyl orange (MO), rohdamine $\mathrm{B}(\mathrm{RhB})$ and chlorophenols (CPs). Indeed, this system is a completely green method of wastewater treatment, and the findings are highly encouraging. The authors found that this system is much better than using $\mathrm{H}_{2} \mathrm{O}_{2}$ alone for the degradation of various organic pollutants such as MB, MO, RhB and CPs as shown in Fig. 1. The enhanced activity was initially attributed to the highly active $\mathrm{HCO}_{4}{ }^{-}$anion, but $\bullet \mathrm{O}_{2}{ }^{-}$was later confirmed as the sole reactive species involved in degradation. This method is also safe for the environment, given that $\mathrm{NaHCO}_{3}$ is abundant and naturally present in surface and ground water. However, the long reaction time may be considered a limitation for its practical application.

\subsection{Activity of homogeneous $\left(\mathrm{M}^{2+} / \mathrm{HCO}_{3}{ }^{-} / \mathrm{H}_{2} \mathrm{O}_{2}\right) \mathrm{BAP}$ system in degradation of organic pollutants}

To date, different metal ions such as $\mathrm{Fe}, \mathrm{Co}, \mathrm{Cu}, \mathrm{Ce}, \mathrm{Mn}, \mathrm{Cr}$ and Mo were reported in catalytic wet peroxide oxidation (CWPO) during wastewater treatment [7]. Among versatile AOPs, Fenton or Fenton like, photo- $\mathrm{H}_{2} \mathrm{O}_{2}$ or electron $-\mathrm{H}_{2} \mathrm{O}_{2}$ are considered more efficient technologies for a wide range of organic pollutants in wastewater treatment [69-73]. However, the ferric ion $\left(\mathrm{Fe}^{3+}\right.$ ) produced through Eq. (4) during degradation is converted to insoluble $\mathrm{Fe}(\mathrm{OH})_{3}$ (sludge) at neutral or nearly neutral $\mathrm{pH}$ that slows down the efficiency of the system, which is a serious drawback in Fenton's system; accordingly, its activity is strictly limited to a low $\mathrm{pH}$ range (2.5-3.5).

$$
\begin{aligned}
& \mathrm{H}_{2} \mathrm{O}_{2}+\mathrm{Fe}^{2+} \rightarrow \bullet \mathrm{OH}+\mathrm{OH}^{-}+\mathrm{Fe}^{3+} \\
& \mathrm{Fe}^{3+}+\mathrm{H}_{2} \mathrm{O}_{2} \leftrightarrow \mathrm{Fe} \cdot \cdots \mathrm{OOH}^{2+}+\mathrm{H}^{+} \\
& \mathrm{Fe} \cdots \mathrm{OOH}^{2+}+\mathrm{H}^{+} \rightarrow \bullet \mathrm{OH}_{2}+\mathrm{Fe}^{2+}
\end{aligned}
$$

Different efforts have been made to overcome this challenge, and in this context, the introduction of BAP using various redox metal ions is currently a new emerging alternative. In the BAP system, the solution $\mathrm{pH}$ remains neutral or slightly alkaline. Recent studies of wastewater treatment using BAP systems with different redox metal ions are summarized in Table 2. These studies provided some encouraging results, such as enhanced de-colorization of organic dyes, in situ formation and stabilization of reactive intermediates, kinetic and mechanism studies. The studies of BAP systems conducted to date have
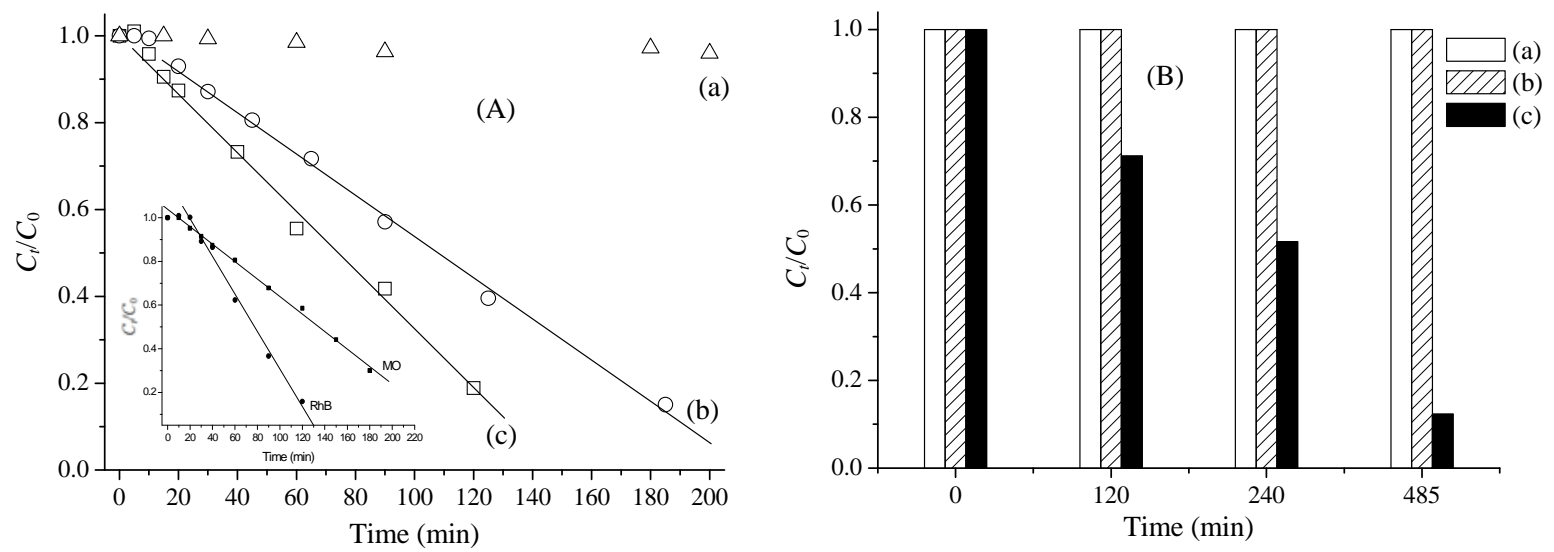

Fig. 1. Degradation of MB (A) and 4-CP (B). Reaction conditions for (A): (a) $\mathrm{NaOH}$ and $\mathrm{H}_{2} \mathrm{O}_{2}$ (pH 8.2), (b) $\mathrm{NaHCO}_{3}$ and $\mathrm{H}_{2} \mathrm{O}$, (c) $\mathrm{NaHCO}_{3}$ and $\mathrm{H}_{2} \mathrm{O}_{2}$ (pre-equilibrium for $20 \mathrm{~min}$ before reaction), $\mathrm{MB} 0.268 \mathrm{mmol} / \mathrm{L}, \mathrm{MO} 0.305 \mathrm{mmol} / \mathrm{L}, \mathrm{RhB} 0.209 \mathrm{mmol} / \mathrm{L}_{2} \mathrm{H}_{2} \mathrm{O}_{2} 0.1 \mathrm{~mol} / \mathrm{L}, \mathrm{NaHCO} 30.5 \mathrm{~mol} / \mathrm{L}, 25{ }^{\circ} \mathrm{C}$. Reaction conditions for (B): (a) $\mathrm{NaOH}$ and $\mathrm{H}_{2} \mathrm{O}_{2}$ (pH 8.2), (b) $\mathrm{NaHCO}_{3}$, (c) $\mathrm{NaHCO}_{3}$ and $\mathrm{H}_{2} \mathrm{O}_{2}, 4-\mathrm{CP} 1.59 \mathrm{mmol} / \mathrm{L}, \mathrm{H}_{2} \mathrm{O}_{2} 0.1 \mathrm{~mol} / \mathrm{L}, \mathrm{NaHCO} 30.5 \mathrm{~mol} / \mathrm{L}, 35$ ${ }^{\circ} \mathrm{C}$. Reproduced from Ref. [68]. 
Table 2

Activity of $\mathrm{M} / \mathrm{HCO}_{3}{ }^{-} / \mathrm{H}_{2} \mathrm{O}_{2}$ system in degradation of organic pollutants.

\begin{tabular}{|c|c|c|c|c|c|c|}
\hline Catalyst system & Target compounds & Removal (\%) & Reaction time (min) & COD removal (\%) & TOC removal (\%) & Ref. \\
\hline $\mathrm{HCO}_{3}{ }^{-} / \mathrm{H}_{2} \mathrm{O}_{2}$ & $\mathrm{MB}, \mathrm{MO}, \mathrm{RhB}$ and $4-\mathrm{CP}$ & 100,88 & $180-300(8 \mathrm{~h}$ for $4-\mathrm{CP})$ & 62 (for only MB) & 23 & [68] \\
\hline $\mathrm{Mn}^{2+} / \mathrm{HCO}_{3}-/ \mathrm{H}_{2} \mathrm{O}_{2}$ & MB, MO, RhB and landfill leachate & 100 & 180 (for only MB) & - & - & [74] \\
\hline $\mathrm{Cu}^{2+} / \mathrm{HCO}_{3}^{-} / \mathrm{H}_{2} \mathrm{O}_{2}$ & AOII, TB, MO, MR, & 100 & 10 (for only AOII) & - & - & [93] \\
\hline $\mathrm{Co} / \mathrm{HCO}_{3}{ }^{-} / \mathrm{H}_{2} \mathrm{O}_{2}$ & $\mathrm{MB}$ & 100 & 50 & 41 & 17 & [95] \\
\hline $\mathrm{Co} / \mathrm{HCO}_{3}{ }^{-} / \mathrm{H}_{2} \mathrm{O}_{2}$ & Red X-3B & 85 & 40 & 46 & 23 & [98] \\
\hline $\mathrm{Co} / \mathrm{HCO}_{3}{ }^{-} / \mathrm{H}_{2} \mathrm{O}_{2}$ & AOII & 100 & - & - & - & [96] \\
\hline $\mathrm{Co} / \mathrm{HCO}_{3}{ }^{-} / \mathrm{H}_{2} \mathrm{O}_{2}$ & MB & 100 & 30 & 42 & 19 & [97] \\
\hline $\mathrm{Co} / \mathrm{HCO}_{3}{ }^{-} / \mathrm{H}_{2} \mathrm{O}_{2}$ & AOII & 100 & 10 & - & - & [99] \\
\hline
\end{tabular}

mainly focused on degradation of dyes with different redox metal ions such as $\mathrm{Co}, \mathrm{Mn}$ and $\mathrm{Cu}$. For example, the $\mathrm{Mn}^{2+} / \mathrm{HCO}_{3}-/ \mathrm{H}_{2} \mathrm{O}_{2}$ system was applied for a variety of dyes and landfill leachate [74-76]. Xu et al. [74] found that the BAP system was very efficient for degradation of $\mathrm{MB}$, as complete de-colorization was achieved in $180 \mathrm{~min}$ (Fig. 2). Similarly, other organic pollutants, such as $\mathrm{MO}, \mathrm{RhB}$ and landfill leachate, were also degraded at different time intervals. Based on kinetics and UV-visible studies, the $\mathrm{Mn}^{\mathrm{IV}}=\mathrm{O}$ species were proposed as possible intermediates involved in degradation. In another study, Ember et al. [75] claimed a clean and rapid degradation of orange II (AOII) with relatively non-toxic $\mathrm{Mn}^{2+}$ salt at $25{ }^{\circ} \mathrm{C}$, and they conducted extensive spectroscopic studies to identify the key features of the degradation mechanism in which $\mathrm{Mn}^{\mathrm{IV}}=0$ was proposed as the primary intermediate.

During the kinetic and mechanistic studies, a similar trend of enhanced degradation was observed for a series of dyes with increasing bicarbonate concentration. Ember et al. [76] reported that the rate constants for all dyes depend on the second order of $\mathrm{HCO}_{3}{ }^{-}$concentration, indicating two equivalents of $\mathrm{HCO}_{3}-$ contribute to degradation in which one equivalent of bicarbonate was proposed to participate in the formation of more reactive $\left[\mathrm{Mn}\left(\mathrm{CO}_{3}\right)\left(\mathrm{H}_{2} \mathrm{O}\right)_{4}\right]$ intermediate, and the other equivalent produces peroxycarbonate. Another important feature of this study is the stability and re-usability of the catalyst system. The authors found that $\mathrm{Mn}^{2+}$ salts are able to form a highly reactive aquatic intermediate that changes to inactive $\mathrm{Mn}$ (II) complex in the absence of any other stabilizing ligands. They also proposed different stoichiometric $\mathrm{Mn}^{2+} . . \mathrm{HCO}_{3}{ }^{-}$complexes with increasing bicarbonate concentration. These complexes were found to be relatively stable and their deactivation occurred in less than $20 \mathrm{~min}$. However, the stability increased (1-4 days) in the presence of some organic dyes at high concentrations of bicarbonate $(0.4$ mol/L), for which the authors provided extensive evidence from different dyes in monodentate manure, including some with low binding affinity or binding in monodentate manure. In all cases, the catalytic cycle was found to repeat several times without significant loss in catalytic activity, which was attributed to in situ stabilization of catalyst with dyes.

Similar studies not involving wastewater treatment also investigated the decomposition of $\mathrm{H}_{2} \mathrm{O}_{2}$ and oxidation of amino acids using the $\mathrm{Mn}^{2+} / \mathrm{HCO}_{3}-/ \mathrm{H}_{2} \mathrm{O}_{2}$ system [77-79]. In these studies, the reaction rate of $\mathrm{H}_{2} \mathrm{O}_{2}$ decomposition was found to increase in a manner directly proportional to $\left[\mathrm{Mn}^{2+}\right]$ and $\left[\mathrm{H}_{2} \mathrm{O}_{2}\right]$ and to the third power of $\mathrm{HCO}_{3}{ }^{-}$concentration [77]. For example, Stadtman et al. [77] proposed the use of three equivalents of $\mathrm{HCO}_{3}-$ combined with one equivalent of $\mathrm{Mn}^{2+}$ to form a stable complex allowing facile reaction between $\mathrm{Mn}^{\mathrm{II}}$ and $\mathrm{H}_{2} \mathrm{O}_{2}$. In another study, the disproportionation of $\mathrm{H}_{2} \mathrm{O}_{2}$ was proportional to $\left[\mathrm{HCO}_{3}^{-}\right]^{3}$, suggesting the formation of an $\mathrm{Mn}^{\mathrm{II}}\left(\mathrm{HCO}_{3}{ }^{-}\right)_{3}$ complex [78]. However, in the presence of amino
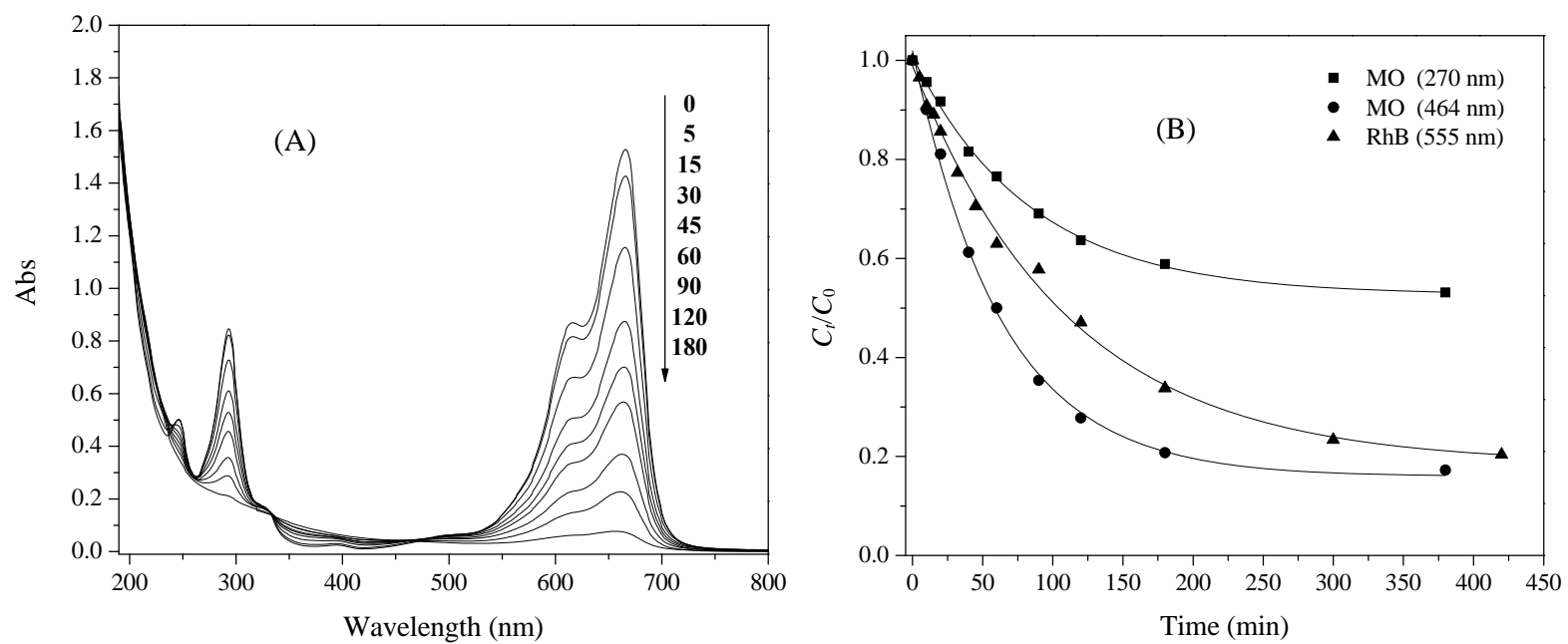

Fig. 2. Catalytic activity of the $\mathrm{Mn}^{2+} / \mathrm{HCO}_{3}-\mathrm{H}_{2} \mathrm{O}_{2}$ system for degradation of $\mathrm{MB}(\mathrm{A}), \mathrm{MO}$ and $\mathrm{RhB}(\mathrm{B})$. Reaction conditions: $25^{\circ} \mathrm{C}, \mathrm{MB} 0.535 \mathrm{mmol} / \mathrm{L}$, MO 0.61, RhB $0.42 \mathrm{mmol} / \mathrm{L}, \mathrm{NaHCO}_{3} 25 \mathrm{mmol} / \mathrm{L}_{,} \mathrm{H}_{2} \mathrm{O}_{2} 99.7 \mathrm{mmol} / \mathrm{L}, \mathrm{MnCl}_{2} 0.1 \mathrm{mmol} / \mathrm{L}$. Reproduced from Ref. [74]. 
acid (AA), the decomposition of $\mathrm{H}_{2} \mathrm{O}_{2}$ is proportional to the square of the $\mathrm{HCO}_{3}{ }^{-}$concentration. The higher efficiency of the suggested complex was a result of the favorable redox potential of $\mathrm{Mn}(\mathrm{II})$ in the $\left(\mathrm{Mn}^{2+}\left(\mathrm{HCO}_{3}\right)_{2} \mathrm{AA}\right)$ complex. The proposed mechanism in this study initially involved the generation of a cage type (Me)-AA- $\mathrm{HCO}_{3}-$ complex that reacts with $\mathrm{H}_{2} \mathrm{O}_{2}$ to produce $\bullet \mathrm{OH}$ radicals very close to the oxidized moiety (oxidized amino acid). To examine the structural identity of free radicals during the oxidation of amino acids and the catalytic decomposition of $\mathrm{H}_{2} \mathrm{O}_{2}$, electron paramagnetic resonance (EPR) with spin trapping using DMPO was conducted by Yim et al. [79]. In this study, the EPR results confirmed the presence of both $\bullet \mathrm{OH}$ and $\bullet \mathrm{O}_{2}{ }^{-}$as intermediates in the dismutation reaction, and $\bullet \mathrm{O}_{2}$ - radical was considered a major product trapped by DMPO. They suggested the formation of $\bullet \mathrm{O}_{2}$ - likely occurred in the inner coordination sphere of metal ions, where the $\bullet \mathrm{OH}$ radicals were also produced. According to the proposed mechanism shown in Scheme 1, transferring the electron from $\mathrm{Mn}^{2+}$ to $\mathrm{H}_{2} \mathrm{O}_{2}$ at the axial position in structure 1 resulted in homolytic cleavage of $\mathrm{H}_{2} \mathrm{O}_{2}$ and the formation of cage $\bullet \mathrm{OH}$ radicals in structure 2 . The majority of - $\mathrm{OH}$ radicals in the cage structure $\mathbf{2}$ then abstract the hydrogen atom from another $\mathrm{H}_{2} \mathrm{O}_{2}$ at the equatorial position to form $\mathrm{HO}_{2} \bullet$. These studies clearly confirmed that the oxidative activity of $\mathrm{Mn}^{2+}$ primarily depends on the concentration of bicarbonate.

Bicarbonate in biological systems has been reported to exist in equilibrium with $\mathrm{CO}_{2}$. In the literature, the oxidative activity of $\mathrm{Cu}, \mathrm{Zn}$ dismutase was initially attributed to bicarbonate for a variety of reactions at physiological conditions [80-86]; however, the actual activity of $\mathrm{Cu}, \mathrm{Zn}$ dismutase was later confirmed to be caused by $\mathrm{CO}_{2}$ rather than bicarbonate [87]. To clarify the actual dependence of $\mathrm{Mn}^{2+}$ reactivity, Liochev et al. [88] conducted a study of the oxidation of NADH. They found an apparent synergism between $\left[\mathrm{HCO}_{3}^{-}\right]$and $\left[\mathrm{CO}_{2}\right]$ during oxidation, and this oxidation was inhibited using Mn-SOD, reflecting the generation of superoxide as an important reactant. Based on the consistent properties of this system, the following Scheme 2, from Eqs (7)-(18), was proposed for the oxidation of $\mathrm{NADH}$.

Copper is known to catalyze the oxygenation of hydrocarbon and demonstrate Fenton's like chemistry during the degradation of organic compounds [89-92]. Cheng et al. [93] reported that, in BAP systems, $\mathrm{Cu}^{2+}$ degrades different

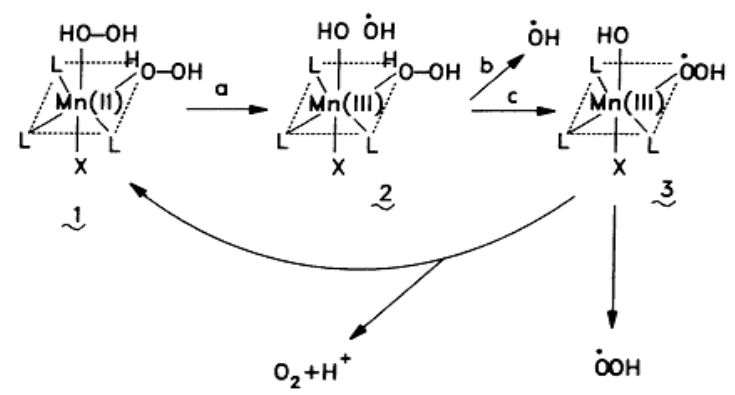

Scheme 1. Proposed scheme for generation of $\bullet \mathrm{OH}$ and $\bullet \mathrm{O}_{2}{ }^{-}$in $\mathrm{Mn}^{2+} / \mathrm{HCO}_{3}-/ \mathrm{H}_{2} \mathrm{O}_{2}$ system. Reproduced from Ref. [79].

$$
\begin{aligned}
& \mathrm{Mn}^{2+}+\mathrm{HCO}_{3}{ }^{-}+\mathrm{H}_{2} \mathrm{O}_{2} \leftrightarrow \mathrm{HCO}_{3}-\mathrm{Mn}^{2+}-\mathrm{OOH}+\mathrm{H}^{+} \\
& \mathrm{HCO}_{3}-\mathrm{Mn}^{2+}-\mathrm{OOH}+\mathrm{H}^{+} \leftrightarrow \mathrm{HCO}_{3}-\mathrm{Mn}^{2+}-\mathrm{OH}+\mathrm{OH}^{-} \\
& \mathrm{HCO}_{3}-\mathrm{Mn}^{2+-} \mathrm{OH}+\mathrm{H}_{2} \mathrm{O}_{2} \leftrightarrow \mathrm{HCO}_{3}-\mathrm{Mn}^{3+}+\bullet \mathrm{O}_{2}^{-}+\mathrm{H}_{2} \mathrm{O}+\mathrm{H}^{+} \\
& 2 \mathrm{HCO}_{3}-\mathrm{Mn}^{3+}+\mathrm{H}_{2} \mathrm{O}_{2} \leftrightarrow 2 \mathrm{HCO}_{3}-\mathrm{Mn}^{2+}+\mathrm{O}_{2}+2 \mathrm{H}^{+} \\
& \mathrm{Mn}^{2+}+\mathrm{CO}_{2}+\mathrm{H}_{2} \mathrm{O}_{2} \leftrightarrow \mathrm{HOO}-\mathrm{Mn}^{2+}-\mathrm{CO}_{2}+\mathrm{H}^{+} \\
& \mathrm{HOO}-\mathrm{Mn}^{2+}-\mathrm{CO}_{2}+\cdot \mathrm{O}_{2}^{-}+\mathrm{H}^{+} \leftrightarrow \mathrm{HO}-\mathrm{Mn}^{2+}-\mathrm{CO}_{2}+\mathrm{O}_{2}+\mathrm{OH}^{-} \\
& \mathrm{HO}-\mathrm{Mn}^{2+-}-\mathrm{CO}_{2}+\mathrm{H}_{2} \mathrm{O}_{2} \leftrightarrow \mathrm{Mn}^{2+}+\mathrm{CO}_{2}+\cdot \mathrm{O}_{2}-+\mathrm{H}_{2} \mathrm{O}+\mathrm{H}^{+} \\
& \mathrm{HOO}-\mathrm{Mn}^{2+-} \mathrm{CO}_{2}+\bullet \mathrm{O}_{2}^{-} \leftrightarrow \mathrm{Mn}^{2+}+\cdot \mathrm{CO}_{3}^{-}+\mathrm{O}_{2}+\mathrm{OH}^{-} \\
& \cdot \mathrm{CO}_{3^{-}}+\mathrm{H}_{2} \mathrm{O}_{2} \leftrightarrow \mathrm{HCO}_{3}^{-}+\mathrm{O}_{2}+\mathrm{H}^{+}+\cdot \mathrm{O}_{2}^{-} \\
& \cdot \mathrm{CO}_{3}{ }^{-}+\mathrm{NADH} \leftrightarrow \mathrm{HCO}_{3}^{-}+\mathrm{NAD} \bullet \\
& \mathrm{NAD} \bullet+\mathrm{O}_{2} \leftrightarrow \mathrm{NAD}^{+}+\bullet \mathrm{O}_{2} \\
& \bullet \mathrm{O}_{2}{ }^{-}+\bullet \mathrm{O}_{2}^{-}+2 \mathrm{H}^{+} \leftrightarrow \mathrm{H}_{2} \mathrm{O}_{2}+\mathrm{O}_{2}
\end{aligned}
$$

Scheme 2. Proposed pathway in $\mathrm{Mn}^{2+}$ activated BAP system for oxidation of NADH. Reproduced from Ref. [88].

dyes including AOII, MO, methyl red, and toluidine blue. The activity of the BAP system with $\mathrm{Cu}^{2+}$ was found to be high enough for complete de-colorization of AOII to occur within 10 min (Fig. 3). In particular, this BAP system was found to be even more efficient than the copper based Fenton's like system, as a very small amount of $\mathrm{Cu}^{2+}(0.01 \mathrm{mmol} / \mathrm{L})$ is sufficient for complete de-colorization, while in the $\mathrm{Cu}^{2+} / \mathrm{H}_{2} \mathrm{O}_{2}$ system, 0.1 $\mathrm{mmol} / \mathrm{L} \mathrm{Cu}^{2+}$ was required for de-colorization of reactive black 5 under neutral or alkaline conditions [94].

Cobalt cation was also reported to be useful for degradation of a wide range of dyes using the BAP system [95-99]. These studies mostly focused on degradation of dyes with other aspects such as degradation mechanism and kinetic studies. In the BAP system using $\left(\mathrm{Co}^{2+} / \mathrm{HCO}_{3}-/ \mathrm{H}_{2} \mathrm{O}_{2}\right)$, there was no direct evidence of the participation of $\bullet \mathrm{OH}$ radicals in the degradation process. For example, in the degradation of MB, Xu at al. [95] proposed the term transient caged $\bullet \mathrm{OH}$ radical as suggested by Yim et al. [79] for dismutation of $\mathrm{H}_{2} \mathrm{O}_{2}$ in the $\mathrm{Mn}^{2+} / \mathrm{HCO}_{3}{ }^{-} / \mathrm{H}_{2} \mathrm{O}_{2}$ system. Here, the authors found that the fluorescence intensity, which was used to quantify $\bullet \mathrm{OH}$ radicals, increased sharply with the addition of bicarbonate. They initially assumed that this reflected the formation of an in situ $\mathrm{Co}^{2+}-\mathrm{HCO}_{3}{ }^{-}$complex between $\mathrm{Co}^{2+}$ ions and $\mathrm{HCO}_{3}$ - ions because of the significant role of bicarbonate in the production of $\bullet \mathrm{OH}$ radicals. This intermediate complex was assumed to act as an in situ catalyst in the activation of $\mathrm{H}_{2} \mathrm{O}_{2}$. In the $\mathrm{CV}$ studies, they later confirmed that this in situ complex $\left(\mathrm{Co}^{2+}-\mathrm{HCO}_{3}-\right)$ shifts the potential peak of the $\mathrm{Co}^{2+}$ ion in a more negative direction. Based on the bicarbonate concentration, they proposed different stoichiometric complexes. For example, a more stable and reactive $\left[\mathrm{Co}^{2+}\left(\mathrm{HCO}_{3}^{-}\right)\right]^{+}$complex was suggested at modest concentration (5-10 mmol/L), while another $\left[\mathrm{Co}^{2+}\left(\mathrm{HCO}_{3}^{-}\right)_{2}\right]$ complex was assumed to exist at high concentration (50-100 mmol/L). The coordination numbers of these complexes were suggested to play important roles in the generation of $\bullet \mathrm{OH}$ radical. For example, bicarbonate at low concentration (0-5 mmol/L) was assumed to produce dimers or oligomers in aquatic $\mathrm{Co}^{2+}$ ions. In such cases, maximum coordination positions are unavailable for $\mathrm{H}_{2} \mathrm{O}_{2}$ to generate efficient $\bullet \mathrm{OH}$ radicals, resulting in lower $\mathrm{MB}$ degradation. Similarly, $\left[\mathrm{Co}^{2+}\left(\mathrm{HCO}_{3}\right)_{2}\right]$ complex with no binding equatorial position 

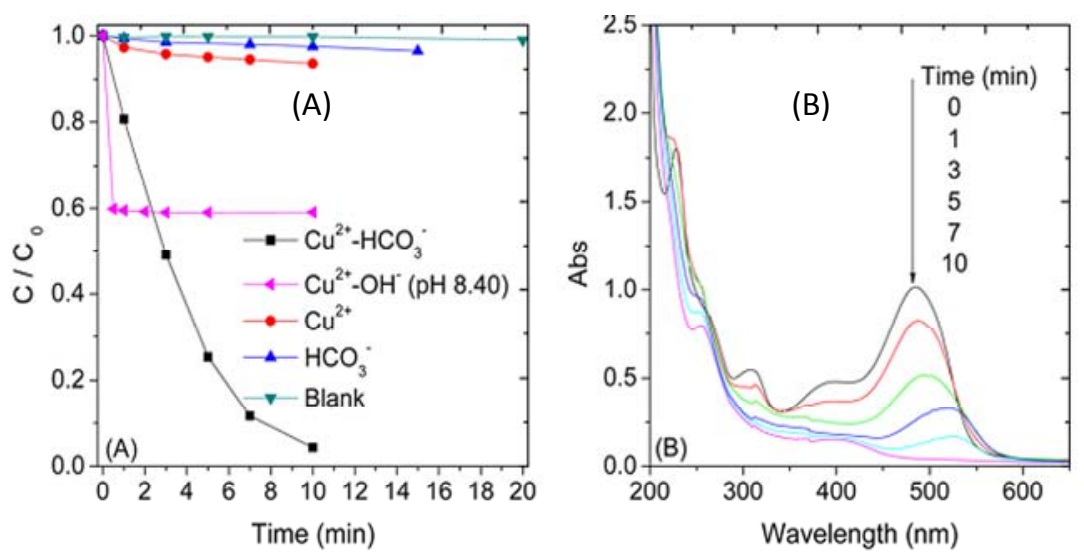

Fig. 3. (A) Evaluation of AOII concentration under different conditions with time and (B) UV-Vis spectral changes in AOII de-colorization in the $\mathrm{Cu}^{2+}-\mathrm{HCO}_{3}{ }^{-}$system. Conditions: $\mathrm{Cu}^{2+} 0.03 \mathrm{mmol} / \mathrm{L}, \mathrm{HCO}_{3}-10 \mathrm{mmol} / \mathrm{L}, \mathrm{H}_{2} \mathrm{O}_{2} 4 \mathrm{mmol} / \mathrm{L}, \mathrm{AOII} 0.05 \mathrm{mmol} / \mathrm{L}, 29^{\circ} \mathrm{C}$. Reproduced from Ref. [93].

was recommended at high bicarbonate concentration (50-100 $\mathrm{mmol} / \mathrm{L})$, which caused lower degradation. However, the $\left[\mathrm{Co}^{2+}\left(\mathrm{HCO}_{3}^{-}\right)\right]+$complex formed at 5-10 mmol/L of bicarbonate was believed to be more stable, which can produce rapid and active transient cage type $\bullet \mathrm{OH}$ radicals.

Similarly, Lou et al. [96] studied the changes in redox properties of $\mathrm{Co}^{2+}$ ions after the addition of $\mathrm{H}_{2} \mathrm{O}_{2}$ during degradation in the BAP system. As shown in Fig. 4, the authors found significant increases in UV-visible absorbance at 260 and $400 \mathrm{~nm}$, which they attributed to oxidation of $\mathrm{Co}^{2+}$ to $\mathrm{Co}^{3+}$. They also observed that the absorbance at $260 \mathrm{~nm}$ initially rapidly increased, then decreased linearly with time (Fig. 4). This behavior was attributed to the initial rapid conversion of $\mathrm{Co}^{2+}$ into high valent state $\mathrm{Co}^{3+}$, and the subsequent slower reduction of $\mathrm{Co}^{3+}$ to $\mathrm{Co}^{2+}$. Based on this behavior, the authors assumed that the production of $\bullet \mathrm{OH}$ radicals occurred during oxidation of $\mathrm{Co}^{2+}$ and $\bullet \mathrm{O}_{2}-$ during the $\mathrm{Co}^{3+}$ reduction process. The existence of $\bullet \mathrm{OH}$ and $\bullet \mathrm{O}_{2}$ - radicals was confirmed by EPR and NBT experiments. However, the term tightly associated -OH radical with cobalt complex was used, as no scavenging of -OH radical occurred, even with high concentrations of 2-propanol. The authors attributed the increase in de-colorization of dye with 2-propanol to the increased stability of free $\bullet \mathrm{O}_{2}$ - radicals in organic solvent, which was also confirmed by SOD scavenging studies.

In continuation of the $\mathrm{Co}^{2+} / \mathrm{HCO}_{3}{ }^{-} / \mathrm{H}_{2} \mathrm{O}_{2}$ system, $\mathrm{Li}$ et al. [97] conducted $\mathrm{CV}$ and $\mathrm{UV}$-visible studies of the coordination behavior of $\mathrm{MB}$ and $\mathrm{Co}^{2+}$ to find clear information describing the reaction mechanism. For example, $\mathrm{CV}$ studies revealed that MB alone produces a clear oxidation peak $\left(E_{\mathrm{a}}=-0.159 \mathrm{~V}\right)$ and reduction peak $\left(E_{\mathrm{c}}=-0.178 \mathrm{~V}\right)$ analogous to the methylene blue/leucomethylene blue redox couple reaction that corresponds to two electron transfer processes. However, in the presence of $\mathrm{Co}^{2+}$ cations, the oxidation peak of $\mathrm{MB}$ was found to decrease with changes in peak current. Similarly, when both $\mathrm{Co}^{2+}$ ions and $\mathrm{HCO}_{3}$ - were present in the system, the oxidation peak of MB shifted to a much lower potential $\left(E_{\mathrm{a}}=\right.$ $-0.095 \mathrm{~V}$ ) with increasing peak intensity, which they attributed to the formation of $\mathrm{Co}^{2+}-\mathrm{MB}$ complexes. They also suggested different stoichiometric $\left[\mathrm{Co}^{2+}(\mathrm{MB})\right]^{+}$complexes for different $\mathrm{Co}^{2+}$ concentrations in bicarbonate solution. These different complexes appeared to change the UV-visible spectra of MB at $664 \mathrm{~nm}$. In the radical scavenger and fluorescence studies, the production of $\bullet \mathrm{OH}$ radicals was detected. However, in the fluorescence studies, the peak intensity was much higher in the presence of $\mathrm{MB}$ than in the $\mathrm{Co}^{2+} / \mathrm{HCO}_{3}{ }^{-} / \mathrm{H}_{2} \mathrm{O}_{2}$ system. This
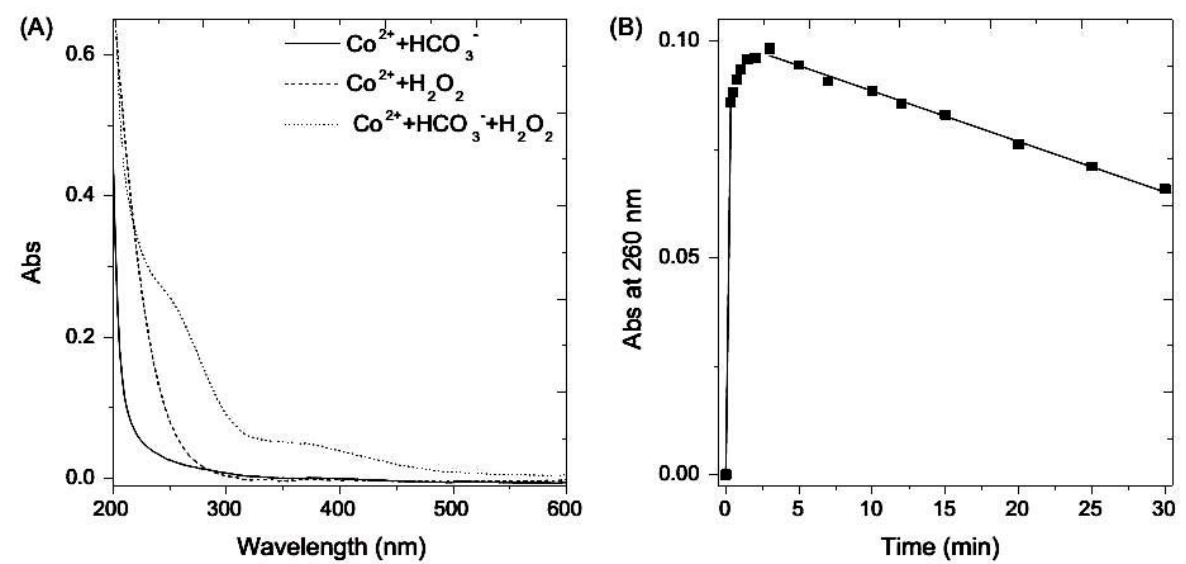

Fig. 4. (A) UV-Vis spectra of $\mathrm{Co}^{2+}-\mathrm{HCO}_{3}{ }^{-}$complex in the presence of $\mathrm{H}_{2} \mathrm{O}_{2}$, and (B) changes in the absorbance at $260 \mathrm{~nm}$ as a function of time. Conditions: $\mathrm{Co}^{2+} 20 \mu \mathrm{mol} / \mathrm{L}(\mathrm{A}), 5 \mu \mathrm{mol} / \mathrm{L}(\mathrm{B}), \mathrm{HCO}_{3}{ }^{-} 10 \mathrm{mmol} / \mathrm{L}, \mathrm{H}_{2} \mathrm{O}_{2} 4 \mathrm{mmol} / \mathrm{L}, 18^{\circ} \mathrm{C}$. Reproduced from Ref. [96]. 


$$
\begin{gathered}
\mathrm{Co}^{2+}+\mathrm{HCO}_{3}^{-} \rightarrow\left[\mathrm{Co}^{2+}\left(\mathrm{HCO}_{3}^{-}\right)\right]^{+} \\
{\left[\mathrm{Co}^{2+}\left(\mathrm{HCO}_{3}^{-}\right)\right]^{+}+\mathrm{MB} \rightarrow\left[\mathrm{Co}^{2+}\left(\mathrm{HCO}_{3}-\right)(\mathrm{MB})\right]^{+}} \\
{\left[\mathrm{Co}^{2+}\left(\mathrm{HCO}_{3}^{-}\right) \mathrm{MB}\right]^{+}+\mathrm{H}_{2} \mathrm{O}_{2} \rightarrow\left[\mathrm{Co}^{2+}\left(\mathrm{HCO}_{3}^{-}\right)(\mathrm{MB})\left(\mathrm{H}_{2} \mathrm{O}_{2}\right)\right]^{+}} \\
{\left[\mathrm{Co}^{2+}\left(\mathrm{HCO}_{3}-(\mathrm{MB})\left(\mathrm{H}_{2} \mathrm{O}_{2}\right)\right]^{+} \rightarrow\right.} \\
{\left[\mathrm{Co}^{3+}\left(\mathrm{HCO}_{3}^{-}\right)(\mathrm{MB})(\bullet \mathrm{OH})\right]^{2+}+\mathrm{OH}^{-}} \\
{\left[\mathrm{Co}^{3+}\left(\mathrm{HCO}_{3}^{-}\right)(\mathrm{MB})(\bullet \mathrm{OH})\right]^{2+} \rightarrow} \\
{\left[\mathrm{Co}^{3+}\left(\mathrm{HCO}_{3}^{-}\right)\right]^{2+}+\text { oxidant product }} \\
{\left[\mathrm{Co}^{3+}\left(\mathrm{HCO}_{3}^{-}\right)\right]^{2+}+\mathrm{H}_{2} \mathrm{O}_{2} \rightarrow\left[\mathrm{Co}^{3+}\left(\mathrm{HCO}_{3}^{-}\right)\right]^{+}+\mathrm{HOO}+\mathrm{H}^{+}}
\end{gathered}
$$

Scheme 3. Proposed mechanism of MB degradation by $\mathrm{Co}^{2+}$ ions with $\mathrm{H}_{2} \mathrm{O}_{2}$ at intermediate $\mathrm{HCO}_{3}{ }^{-}$concentration. Reproduced from Ref. [97].

increase in fluorescence intensity was attributed to the role of $\mathrm{MB}$ in the generation of $\bullet \mathrm{OH}$ radicals, which was supported by the findings in EPR studies. These studies [95-97] relied on the generation of transient cage $\bullet \mathrm{OH}$ radicals during the oxidative degradation of pollutants. Based on the consistent experimental results, the following general degradation pathway Eqs. (19)-(24) was suggested during pollutants degradation [97].

Despite the high de-colorization rate of dyes in the $\mathrm{Co}^{2+} / \mathrm{HCO}_{3}{ }^{-} / \mathrm{H}_{2} \mathrm{O}_{2}$ system, the degree of mineralization (COD and TOC removal) in the reviewed studies is very limited [95, 97-98]. One possible protocol for obtaining good efficiency is the combination of different systems. Normally, AOPs are recommended to improve the biodegradability, while subsequent biological treatment is recommended for final degradation [98]. Yang et al. [98] applied the BAP system to improve the biodegradability of $\mathrm{X}-3 \mathrm{~B}$ before the biodegradation system [98]. The ratio of $\mathrm{BOD}_{5} / \mathrm{COD}$ is usually expressed as biodegradability, and a value higher than 0.30 indicates that the wastewater can be effectively degraded with biological treatment [98]. The authors observed that, as shown in Fig. 5, the biodegradability factor for the BAP system improved from 0.1 to 0.46 or higher when there were high concentrations of $\mathrm{H}_{2} \mathrm{O}_{2}$, indicating that the BAP system may be suitable for pretreatment before application of biological treatment.

The efficiency of the system is the most important factor when evaluating its practical application. In general, these studies have shown excellent efficiency in the de-colorization of different dyes, even when small amounts of transition metals are utilized (Table 2). Importantly, in the studied metal ions, $\mathrm{Co}^{2+}$ showed the best efficiency, followed by $\mathrm{Mn}^{2+}$ and $\mathrm{Cu}^{2+}$ [95]. However, the remaining metals, including $\mathrm{Fe}^{2+}$ and $\mathrm{Ag}^{+}$, showed minor efficiency. Comparative studies of BAP systems with ordinary Fenton's systems revealed that $\mathrm{Co}^{2+} / \mathrm{HCO}_{3}{ }^{-} / \mathrm{H}_{2} \mathrm{O}_{2}$ is more efficient than the Fenton's system [99]. For example, 5 $\mu \mathrm{mol} / \mathrm{L}$ of $\mathrm{Co}^{2+}$ is sufficient to de-colorize AOII dye within 10 min, while $\mathrm{Fe}^{2+}$ at this concentration ( $\mathrm{pH} 3.0$ ) provided only $25 \%$ de-colorization. The selective removal of more toxic compounds in the presence of less toxic ones is extremely difficult. However, this system is able to degrade AOII in the presence of numerous pollutants including $\mathrm{MB}$, sulforhodamine $\mathrm{B}$, as well as inorganic anions including $\mathrm{Cl}^{-}, \mathrm{CO}_{3}{ }^{2-}, \mathrm{SO}_{4}{ }^{2-}, \mathrm{NO}_{3}{ }^{-}$, and $\mathrm{HPO}_{4}{ }^{2-}$ [99].

The application of direct metal ions as catalysts will never be considered safe during wastewater treatment using the BAP system. Although some author's have claimed only very small amounts of metals ions (e.g., 5-20 $\mu \mathrm{mol} / \mathrm{L}$ of Co) were discharged during treatment [95-99], these concentrations will rise owing to the lack of a feasible recovery system, resulting in heavy metal pollution. To date, only three metal ions, $\mathrm{Mn}^{2+}, \mathrm{Cu}^{2+}$ and $\mathrm{Co}^{2+}$, have shown excellent activity in BAP systems, while other metals, including $\mathrm{Fe}^{2+}$ and $\mathrm{Ag}^{+}$, were found to be less reactive [74,93,95-99]. Among the tested metal ions, $\mathrm{Co}^{2+}$ is able to degrade a variety of dyes including $\mathrm{MB}, \mathrm{RhB}, \mathrm{MO}, \mathrm{X}-3 \mathrm{~B}$, AOII, and sulforhodamine $B$ under mild reaction conditions [95-99]. However, dyes represent only one class of pollutants as wastewater is composed of mixtures of versatile organic pollutants. Therefore, it is important to evaluate the efficiency of the $\mathrm{Co}^{2+} / \mathrm{HCO}_{3}-/ \mathrm{H}_{2} \mathrm{O}_{2}$ system when applied to other classes of pollutants such as phenolic compounds, which are difficult to degrade and pose significant threats to the environment. Xiao et al. [97] reported that the $\mathrm{Co}^{2+} / \mathrm{HCO}_{3}{ }^{-} / \mathrm{H}_{2} \mathrm{O}_{2}$ system is very efficient for de-colorizing different azo dyes (reactive brilliant red $\mathrm{X}-3 \mathrm{~B}$ and methyl orange) and triphenylemethane dyes (sulforhodamine B and RhB). However, as shown in Fig. 6, its activity toward phenolic compounds (e.g., p-nitrophenol (PNP), 2,4-dinitrophenol (DNP)) is negligible, and only 7\% PNP was
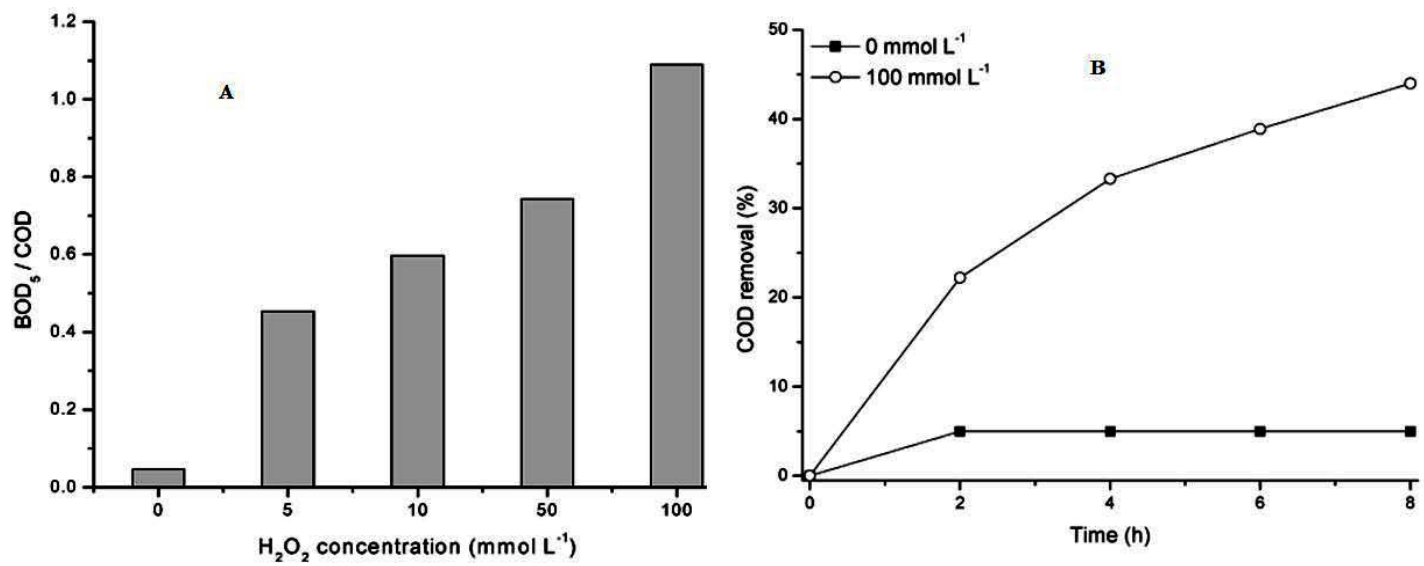

Fig. 5. (A) Effect of $\mathrm{H}_{2} \mathrm{O}_{2}$ concentration on COD removal of $\mathrm{X}-3 \mathrm{~B}$ in $\mathrm{Co}^{2+}-\mathrm{HCO}_{3}{ }^{-}$system, (B) evolution of COD in the bioreactor for X-3B treated with different concentrations of $\mathrm{H}_{2} \mathrm{O}_{2}$. Conditions: $\mathrm{Co}^{2+} 5 \mu \mathrm{mol} / \mathrm{L}, \mathrm{NaHCO}_{3} 10 \mathrm{mmol} / \mathrm{L}$ and X-3B 0.34 mmol/L, $25^{\circ} \mathrm{C}$. Reproduced from Ref. [98]. 

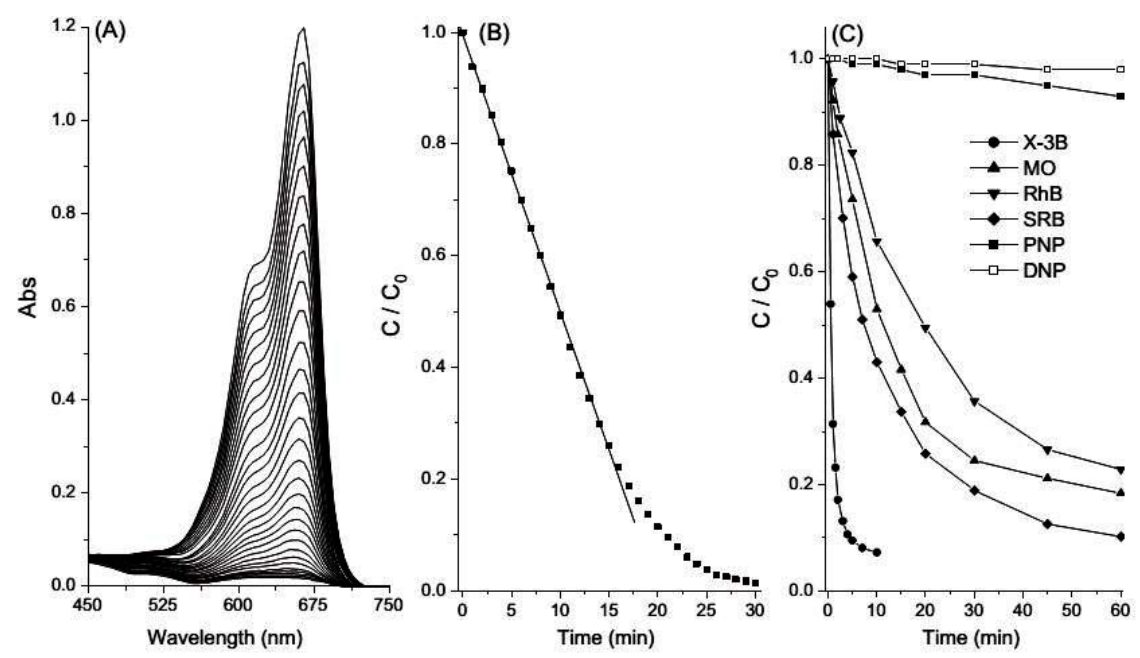

Fig. 6. Degradation of organic pollutants with $\mathrm{Co}^{2+}-\mathrm{HCO}_{3}--\mathrm{H}_{2} \mathrm{O}_{2}$ system. (A) UV-Vis absorption spectra of MB solution during the reaction; (B) Degradation kinetics of MB; (C) Degradation of other organic pollutants. Conditions: $\mathrm{Co}^{2+} 10 \mu \mathrm{mol} / \mathrm{L}, \mathrm{NaHCO}_{3} 10 \mathrm{mmol} / \mathrm{L}, \mathrm{H}_{2} \mathrm{O}_{2} 10 \mathrm{mmol} / \mathrm{L}$, organic pollutants $17.7 \mu \mathrm{mol} / \mathrm{L}$ and $25^{\circ} \mathrm{C}$. Reproduced from Ref. [97].

removed, while DNP was not degraded. Among transition metal ions that catalyzed oxidation of wastewater, manganese is an efficient, economical and environmentally friendly catalyst. In the BAP system, $\mathrm{Mn}^{2+}$ salt was applied by $\mathrm{Xu}$ et al. [74] and Ember et al. [75-76] for degradation of series of dyes (aromatic azo dyes, aromatic azo dyes with adjacent functional groups, flavonoid dyes and phenolic derivatives) under mild reaction conditions. The results of these studies demonstrated that $\mathrm{Mn}^{2+}$ produces different reactive intermediates that, in the absence of any further coordinating ligands, rapidly decomposed into insoluble $\mathrm{Mn}(\mathrm{OH})_{2}, \mathrm{MnCO}_{3}$ or $\mathrm{MnO}_{2}$. They also found that these intermediates can be stabilized with electron rich organic molecules such as dyes. For example, Ember et al. [75] investigated the stability of catalyst formed in situ by exposing the catalyst to dye in bicarbonate solution for $20 \mathrm{~h}$. The catalyst formed in situ showed excellent stability and demonstrated the same reactivity as fresh catalyst with the addition of $\mathrm{H}_{2} \mathrm{O}_{2}$. Moreover, the stability and efficiency of this in situ formed catalyst increased with substitution of functional groups in aromatic azo dyes adjacent to azo linkages. These studies also revealed that the degradation of dyes with aquatic $\mathrm{Mn}^{2+}$ is only possible in the presence of bicarbonate buffer and $\mathrm{H}_{2} \mathrm{O}_{2}$. Indeed, no other buffer containing aqueous $\mathrm{Mn}^{2+}$ ions is able to de-colorize the dyes, which was attributed to amplification of $\mathrm{HCO}_{4}^{-}$as a key reactive species. Ember et al. [76] found that the $\mathrm{Mn}^{2+} / \mathrm{HCO}_{3}-/ \mathrm{H}_{2} \mathrm{O}_{2}$ system is highly sensitive to solution $\mathrm{pH}$. The activity of this system was found to be highest at $\mathrm{pH}$ 8.2-8.6. At high $\mathrm{pH}(\geq 9.0)$, the decrease in the degradation rate was attributed to deprotonation of $\mathrm{HCO}_{4}$ - to less electrophiylic $\mathrm{CO}_{4}{ }^{2-}$ oxidant or decomposition of $\mathrm{H}_{2} \mathrm{O}_{2}$, respectively.

Currently, it is difficult to compare different homogeneous BAP systems employing $\mathrm{Co}, \mathrm{Mn}$ and $\mathrm{Cu}$ metal ions when applied to the treatment of wastewater. To date, these studies have focused on the degradation of dyes with special interest on reaction kinetics and mechanism. In general, these BAP systems show excellent efficiency during degradation of dyes, with slight differences in the nature of reactive species responsible for degradation. For example, in the $\mathrm{Co}^{2+} / \mathrm{HCO}_{3}{ }^{-} /$ $\mathrm{H}_{2} \mathrm{O}_{2}$ system, the reactivity was mainly attributed to the formation of in situ active catalyst $\left(\left[\mathrm{Co}^{2+}\left(\mathrm{HCO}_{3}^{-}\right)\right]^{+}\right)$, while for the $\mathrm{Mn}^{2+}$ based BAP $\left(\mathrm{Mn}^{2+} / \mathrm{HCO}_{3}-/ \mathrm{H}_{2} \mathrm{O}_{2}\right)$ system, they proposed the in situ active catalyst $\left(\left[\mathrm{Mn}^{2+}\left(\mathrm{HCO}_{3}^{-}\right)\right]^{+}\right)$, high valent $\mathrm{Mn}^{\mathrm{IV}}=0$ species and $\mathrm{HCO}_{4}^{-}$as key reactive intermediates for degradation of dyes. However, a completely different mechanism was proposed in the $\mathrm{Cu}^{2+} / \mathrm{HCO}_{3}-/ \mathrm{H}_{2} \mathrm{O}_{2}$ system. For example, Long et al. [93] found that the contribution of $\mathrm{HCO}_{4}^{-}$ or $\mathrm{Cu}^{2+}-\mathrm{HCO}_{4}{ }^{-}$for degradation of dyes was not so important in the $\mathrm{Cu}^{2+} / \mathrm{HCO}_{3}-/ \mathrm{H}_{2} \mathrm{O}_{2}$ system. Similarly, the negligible role of free radicals suggested by scavenger studies strengthens the argument that higher oxidation state copper $\left(\mathrm{Cu}^{3+}\right)$ acts as the sole reactive species involved in degradation of dyes.

\subsection{Application of heterogeneous ( $\mathrm{Cat} / \mathrm{HCO}_{3}-/ \mathrm{H}_{2} \mathrm{O}_{2}$ ) BAP system in degradation of organic pollutants}

In view of heavy metal toxicity, the use of metal ions as homogeneous catalysts is not safe for the treatment of wastewater. Obviously, the strategy of incorporating these active metals on certain supports is the best choice to minimize the threat associated with heavy metals. However, the heterogeneous catalysts prepared when adopting such a strategy are also subject to various problems, including low efficiency and poor stability. For example, various acidic products can be produced during degradation, which encourages catalyst leaching because of low $\mathrm{pH}$ and causes poor catalyst stability $[29,100,101]$. As in homogeneous systems, the recovery of dissolved metal ions is nearly impossible or need expensive treatment. Accordingly, the application of heterogeneous catalyst in BAP systems will be a good choice for wastewater treatment [29,100-102]. This method was first applied in a BAP system by Zhou et al. [29], who used Co supported-diatomite clay as a heterogeneous catalyst for degradation 


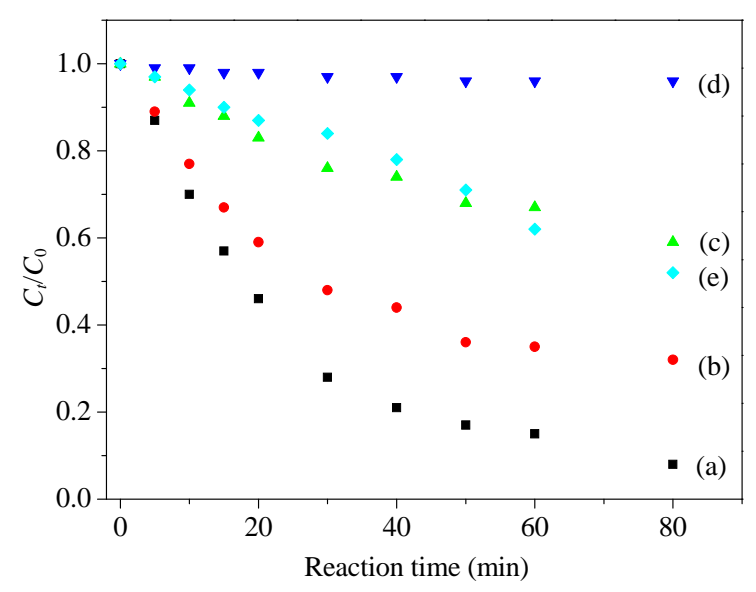

Fig. 7. Degradation of methylene blue $(50 \mathrm{mg} / \mathrm{L})$ with $\mathrm{H}_{2} \mathrm{O}_{2}(60 \mathrm{mmol} / \mathrm{L}$ under different conditions: (a) $25 \mathrm{mmol} / \mathrm{L} \mathrm{NaHCO}_{3}$, diatomite supported cobalt $0.01 \mathrm{~g}, 25^{\circ} \mathrm{C}$; (b) pH 8.2 adjusted with $\mathrm{NaOH}, 0.01 \mathrm{~g}, 25^{\circ} \mathrm{C}$; (c) diatomite supported cobalt $0.01 \mathrm{~g}, 25^{\circ} \mathrm{C}$; (d) $25 \mathrm{mmol} / \mathrm{L} \mathrm{NaHCO}_{3}$; (e) 25 $\mathrm{mmol} / \mathrm{L} \mathrm{NaHCO}_{3}$, and $3.9 \mu \mathrm{mol} / \mathrm{L} \mathrm{Co}\left(\mathrm{NO}_{3}\right)_{2}$. Reproduced from Ref. [29].

of dyes (Fig. 7). The efficiency of heterogeneous catalyst was much better when compared with different control experiments, including homogeneous cobalt ions under the same conditions, and the supported catalyst was found to present excellent stability $(180 \mathrm{~h})$ in a fixed bed reactor. This prolonged catalyst lifetime was attributed to bicarbonate, which provides a weak alkaline buffer throughout the degradation, resulting in improved catalyst stability (Co leaching, $0.24 \mathrm{ppm}$ or smaller).

The nature of the support is very important in heterogeneous catalysts, as it can encourage effective interactions between metal ions and support, improve the distribution of active components, and retain the properties of impregnated metals [103]. Hydrotalcites based materials present unique properties as catalyst support, including modulating its properties by varying metal proportions or replacing different metal cations within the layered structure [104]. Cobalt supported-LDH catalysts (Co-MgAl-LDH) were recently applied for degradation of phenolic compounds and dyes, which highlighted the importance of bicarbonate on process efficiency, catalyst stability and leaching $[100,101]$. During degradation of 4-CP, Jawad et al. [100] found that the activity of a BAP system in the presence of bicarbonate was consistently higher than in various control experiments, even when a small amount of bicarbonate was used (Fig. 8). Similarly, they observed less catalyst leaching $(0.14 \mathrm{mg} / \mathrm{L})$ than in previous studies [29]. The authors attributed this to bicarbonate addition as well strong linkages in the LDH structure. The supported catalyst in the fixed bed test was found to present complete stability with excellent activity (Fig. 9). Again, this stability was attributed to bicarbonate addition, which provides constant $\mathrm{pH}$ (8.84-8.98) throughout the $300 \mathrm{~h}$ reaction, thereby controlling leaching (0.20-0.24 ppm).

In continuation of the BAP system with supported catalysts, another study targeted both the degradation of cationic and anionic dyes (MB and MO) at the bench level and in a fixed bed reactor [101]. In this study, Jawad et al. [101] found that $1.7 \%$ Co loading in Co-MgAl-LDH catalyst was sufficient for

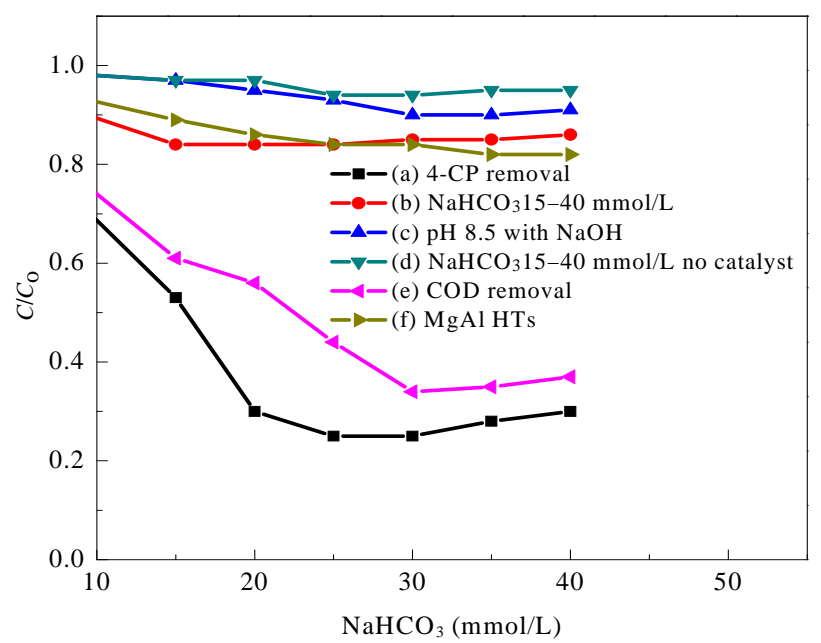

Fig. 8. Influence of $\mathrm{NaHCO}_{3}$ on the degradation of 4-CP. Conditions: (a) 4-CP $100 \mathrm{ppm}, \mathrm{H}_{2} \mathrm{O}_{2} 20 \mathrm{mmol} / \mathrm{L}, 15-40 \mathrm{mmol} / \mathrm{L} \mathrm{NaHCO}_{3}$, temperature $40{ }^{\circ} \mathrm{C}$, catalyst $0.03 \mathrm{~g}$, reaction time $1 \mathrm{~h}$; (b) $15-40 \mathrm{mmol} / \mathrm{L} \mathrm{NaHCO}_{3}$ with no $\mathrm{H}_{2} \mathrm{O}_{2}$ under condition (a); (c) condition (a) $+1 \mathrm{~mol} / \mathrm{L} \mathrm{NaOH}$, no $\mathrm{NaHCO}_{3}$; (d) condition (a) + 15-40 mmol/L $\mathrm{NaHCO}_{3}$ without catalyst (e removal of COD under condition (a); (f) condition (a) + $0.03 \mathrm{~g}$ MgHTs as catalyst. Reproduced from Ref. [100].

de-colorization of both cationic and anionic dyes (Fig. 10). The CoMgAl catalyst was found to be more reactive than CoAl, $\mathrm{CoMg}, \mathrm{MgAl}$ and CuMgAl catalysts, and this behavior was considered to be a function of geometric structure and arrangements of $\mathrm{Co}^{2+}$ in the crystal lattice of LDH. As shown in Fig. 11, the addition of bicarbonate resulted in enhanced catalyst activity relative to control experiments. As shown in Fig. 12, the catalyst stability in the fixed bed was even better than the last two reported studies $[29,100]$. This excellent stability of the supported LDH based catalyst was attributed to the absence of Co leaching throughout the $300 \mathrm{~h}$ reaction.

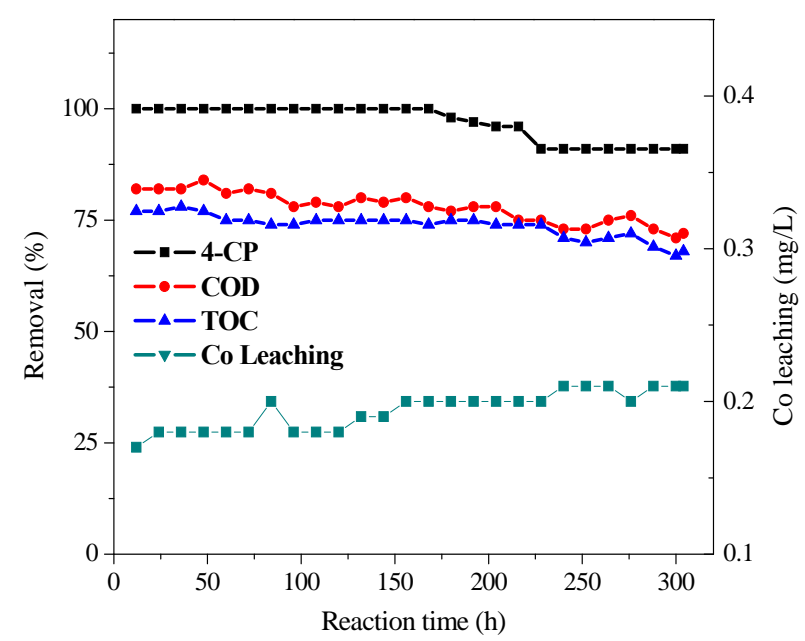

Fig. 9. 4-Chlorophenol degradation, COD and TOC removal in fixed bed down-flow reactor. Conditions: reactor (height, $60 \mathrm{~cm}$; inner diameter, $1 \mathrm{~cm}), 15 \mathrm{~g}$ of support catalyst (cylindrical blocks; length, $5 \mathrm{~mm}$ diameter $4 \mathrm{~mm}$ ), $50 \mathrm{ppm} 4-\mathrm{CP}$ solution, $30 \mathrm{mmol} / \mathrm{L} \mathrm{H}_{2} \mathrm{O}_{2}$ and $\mathrm{NaHCO}_{3}$ oxidant solution, flow rate (chlorophenol/oxidant, 1:1, v/v) $47 \mathrm{~mL} / \mathrm{h}$, retention time $24 \mathrm{~min}, 40^{\circ} \mathrm{C}$. Reproduced from Ref. [100]. 

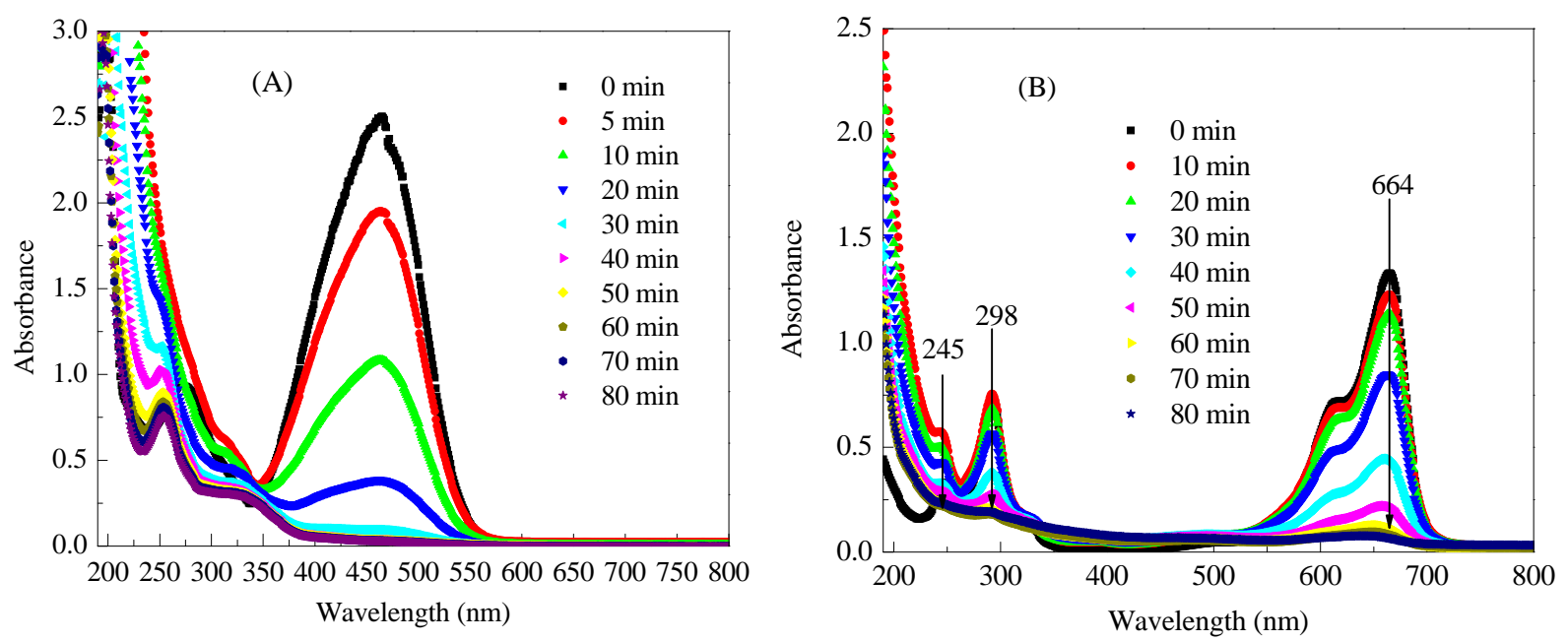

Fig. 10. UV-Vis spectral changes in $\mathrm{HCO}_{3}{ }^{-}$/catalyst system. (A) Methylene orange; (b) Methylene blue. Conditions: target compound 50 ppm, NaHCO $25 \mathrm{mmol} / \mathrm{L}, \mathrm{H}_{2} \mathrm{O}_{2} 50 \mathrm{mmol} / \mathrm{L}$, catalyst $0.03 \mathrm{~g}, 30^{\circ} \mathrm{C}, 0-80 \mathrm{~min}$. Reproduced from Ref. [101].

The degradation of acid orange 7 was recently reported by Duan et al. [102] using a BAP system with $\mathrm{Co}_{x} \mathrm{O}_{y}$-N/GAC catalyst as shown in Fig. 13. The authors described this high activity for the formation of active complexes between cobalt and $\mathrm{HCO}_{3}{ }^{-}$, which produced various reactive oxygen species upon reaction with $\mathrm{H}_{2} \mathrm{O}_{2}$. The $\mathrm{Co}_{x} \mathrm{O}_{y}$-N/GAC catalyst also showed excellent stability, even after successive runs (Fig. 14). The catalyst activity gradually decreased and finally dropped to $32.8 \%$ after the fifth run. This deactivation was attributed to the deposition of intermediate product over the catalyst surface. After drying at $350{ }^{\circ} \mathrm{C}$ under $\mathrm{N}_{2}$, the catalyst recovered its activity as shown in the sixth run. The good stability of the catalyst at this point was assumed to reflect the interaction of cobalt and nitrogen in $\mathrm{Co}_{x} \mathrm{O}_{y}$-N/GAC catalyst, which led to lower catalyst leaching $(0.02 \mathrm{ppm})$. This system appeared to be more promising than the homogeneous BAP system in terms of activity and minimum risk to the environment.

In $\mathrm{H}_{2} \mathrm{O}_{2}$ based advanced oxidations, different mechanisms

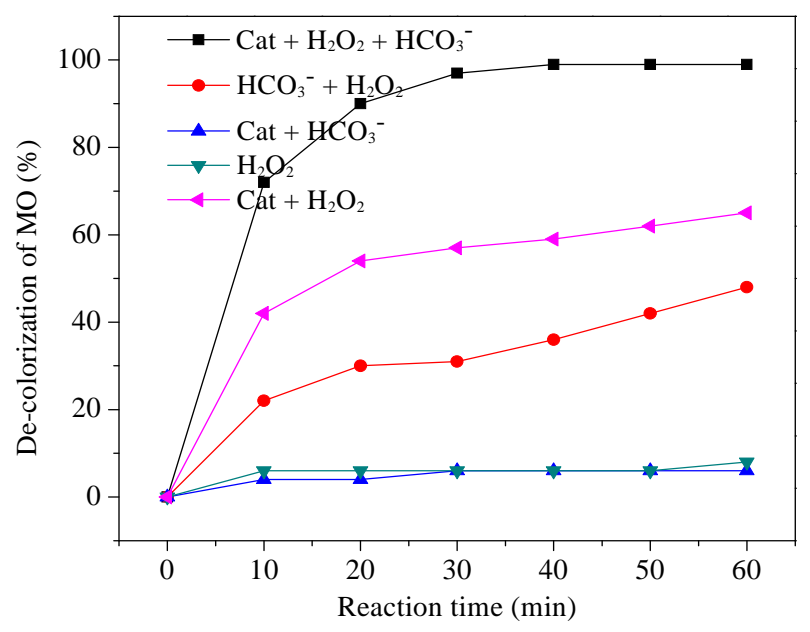

Fig. 11. Influence of bicarbonate on the degradation of MO. Conditions: MO 50 ppm, $\mathrm{NaHCO}_{3} 25 \mathrm{mmol} / \mathrm{L}, \mathrm{H}_{2} \mathrm{O}_{2} 50 \mathrm{mmol} / \mathrm{L}, 0.03 \mathrm{~g}, 30^{\circ} \mathrm{C}$. Reproduced from Ref. [101]. like formation of free radicals, high valent metal oxo species or both mechanisms were generally proposed during degradation of organic pollutants [96]. Most BAP systems using heterogeneous catalysts have relied on the generation of various reactive oxygen species as confirmed by scavengers, fluorescence and EPR studies [29,100-102]. For example, popular scavengers such as ascorbic acid, t-butanol (TBA), sodium azide $\left(\mathrm{NaN}_{3}\right)$ and benzoquinone (BQ) were applied to detect $\bullet \mathrm{OH},{ }^{1} \mathrm{O}_{2}$ and $\bullet \mathrm{O}_{2}$ - radicals, respectively [29,100-102]. The decrease in degradation rates with the addition of a particular scavenger was attributed to participation of the respective ROS. For example, Zhou et al. [29] suggested ${ }^{1} \mathrm{O}_{2}$ was the sole reactive species in the BAP system owing to the apparent inhibition of degradation of MB by sodium azide. They suggested that $\bullet \mathrm{OH}$ radicals indirectly promoted the generation of other ROS such as - $\mathrm{CO}_{3}{ }^{-}$and ${ }^{1} \mathrm{O}_{2}$ through a series of reactions Eqs. (2)-(3), (25)-(29). In another study, Jawad et al. [100,101] suggested the involvement of $\bullet \mathrm{OH}$ and $\bullet \mathrm{O}_{2}$ - radicals based on the scav-

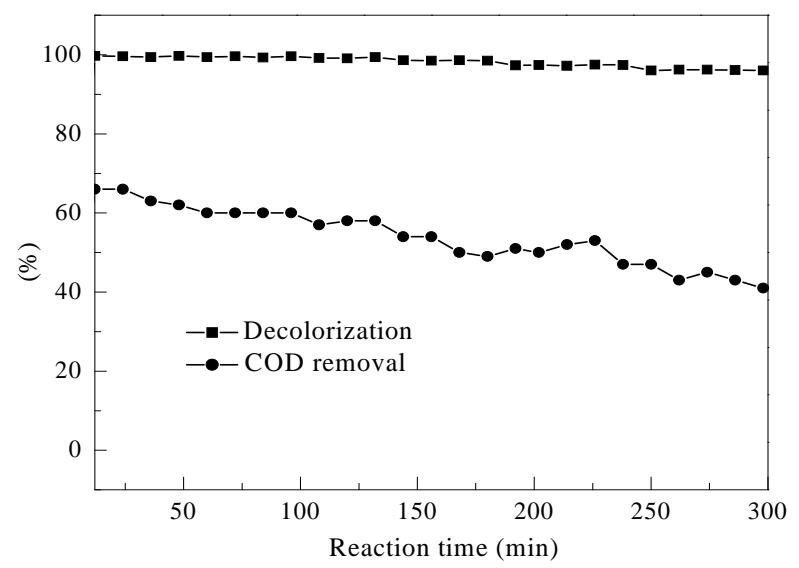

Fig. 12. Degradation of MB in fixed bed down flow glass reactor. Conditions: reactor (height, $60 \mathrm{~cm}$; inner diameter, $1 \mathrm{~cm}$ ), CoMgAl-Na-Y $20 \mathrm{~g}$, MB $60 \mathrm{ppm}$, oxidant $\left(25 \mathrm{mmol} / \mathrm{L} \mathrm{NaHCO}_{3}, 48 \mathrm{mmol} / \mathrm{L} \mathrm{H}_{2} \mathrm{O}_{2}\right.$ ) with flow rate $60 \mathrm{~mL} / \mathrm{h}$ of $\mathrm{MB} /$ oxidant $(1: 1, \mathrm{v} / \mathrm{v})$, retention time $16 \mathrm{~min}, 30^{\circ} \mathrm{C}$. Reproduced from Ref. [101]. 

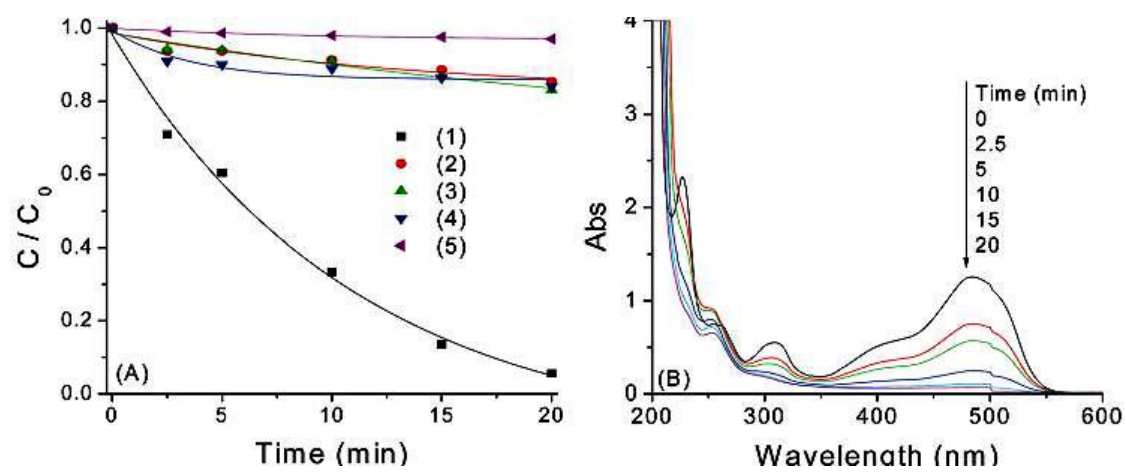

Fig. 13. (A) Degradation of AO7 with different systems. (1) $\mathrm{Co}_{x} \mathrm{O}_{y}-\mathrm{N} / \mathrm{GAC}+\mathrm{NaHCO}_{3} / \mathrm{H}_{2} \mathrm{O}_{2}$; (2) $\mathrm{Co}_{x} \mathrm{O}_{y}-\mathrm{N} / \mathrm{GAC}+\mathrm{NaHCO}_{3}$; (3) $\mathrm{GAC}+\mathrm{NaHCO}_{3} / \mathrm{H}_{2} \mathrm{O}_{2}$; (4) $\mathrm{Co}_{x} \mathrm{O}_{y}-\mathrm{N} / \mathrm{GAC}+\mathrm{NaHCO}_{3} / \mathrm{H}_{2} \mathrm{O}_{2}$ (pH 8.6); (5) $\mathrm{NaHCO}_{3} / \mathrm{H}_{2} \mathrm{O}_{2}$. (B) UV-Vis spectra changes for AO7 degradation with $\mathrm{Co}_{x} \mathrm{O}_{y}-\mathrm{N} / \mathrm{GAC}+\mathrm{NaHCO}_{3} / \mathrm{H}_{2} \mathrm{O}_{2}$ system. Conditions: $\mathrm{Co}_{x} \mathrm{O}_{y}-\mathrm{N} / \mathrm{GAC} 1 \mathrm{~g} / \mathrm{L}, \mathrm{GAC} 1 \mathrm{~g} / \mathrm{L}, \mathrm{NaHCO}_{3} 5 \mathrm{mmol} / \mathrm{L}, \mathrm{H}_{2} \mathrm{O}_{2} 10 \mathrm{mmol} / \mathrm{L}, \mathrm{AO} 750 \mu \mathrm{mol} / \mathrm{L}, 25^{\circ} \mathrm{C}$. Reproduced from Ref. [102].

enging effect of TBA, ascorbic acid and BQ in the degradation of 4-CP and dyes. Apart from scavengers, some other techniques such as fluorescence and EPR studies were considered to be more sensitive for detecting different ROS in reaction medium [97]. In a fluorescence study, fluorescent reagents such as sodium terepthalic acid (NaTA) were reacted with $\bullet \mathrm{OH}$ to give 2-hydroxyterepthalic acid (HTA), which provides sharp, bright and stable fluorescence [97]. This reaction is considered to be unaffected by other reactive species such as $\mathrm{H}_{2} \mathrm{O}_{2}, \mathrm{HO}_{2} \bullet$ and $-\mathrm{O}_{2}-$ [97]. The peak intensity of the fluorescence is considered proportional to the amount of $\bullet \mathrm{OH}$ radicals produced in the reaction [97]. Similarly, nitrone based cyclic spin traps that generate characteristic signals after trapping different free radicals in reactions such as (5,5-dimethyl-1-pyrroline $\mathrm{N}$-oxide) (DMPO) and acyclic $N$-tert-butyl- $\alpha$-phenylnitrone (PBN) are recommended in EPR studies [105]. Jawad et al. [100] applied both fluorescence and EPR techniques to confirm the radicals as suggested in scavenger studies. Their fluorescence studies revealed sharp fluorescence with intensity that decreased with the addition of TBA, which the authors attributed to $\bullet \mathrm{OH}$ radicals. The occurrence of $\bullet \mathrm{OH}$ radicals were further confirmed through EPR, where DMPO gives quartet

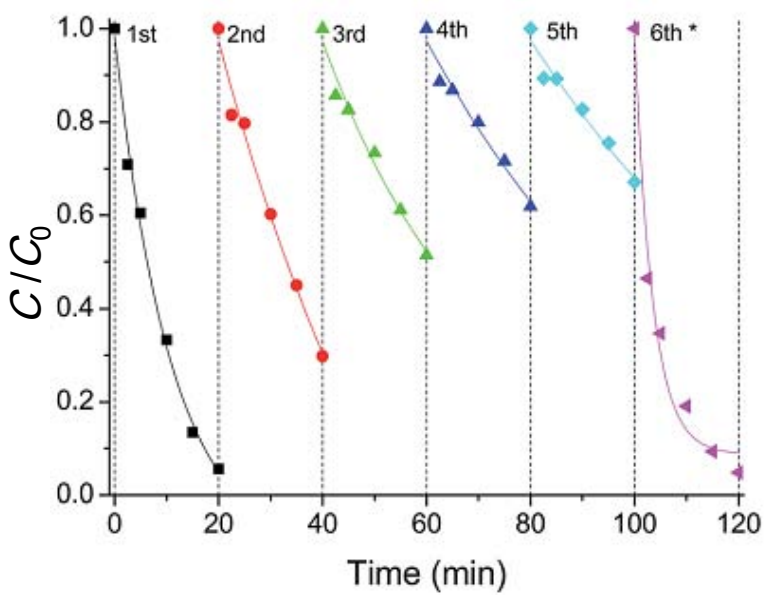

Fig. 14. Degradation of $\mathrm{AO} 7 \mathrm{using} \mathrm{Co}_{x} \mathrm{O}_{y}$-N/GAC catalyst (6th*: the catalyst was thermally treated at $350{ }^{\circ} \mathrm{C}$ under $\mathrm{N}_{2}$ for $1 \mathrm{~h}$ after the fifth run). Conditions: $\mathrm{Co}_{x} \mathrm{O}_{y}-\mathrm{N} / \mathrm{GAC} 1 \mathrm{~g} / \mathrm{L}, \mathrm{HCO}_{3}-5 \mathrm{mmol} / \mathrm{L}, \mathrm{H}_{2} \mathrm{O}_{2} 10 \mathrm{mmol} / \mathrm{L}, \mathrm{AO} 7$ $50 \mu \mathrm{mol} / \mathrm{L} 25^{\circ} \mathrm{C}$. Reproduced from Ref. [102]. signals of DMOP-OH (1:2:2:1 in intensity), which are characteristic signals of $\bullet \mathrm{OH}$ radicals. Moreover, the presence of $\bullet \mathrm{O}_{2}{ }^{-}$was confirmed using PBN as a spin trap, which produces specific triplet $\mathrm{BPN}^{-\mathrm{O}_{2}-}$ signals in EPR studies. However, Jawad et al. $[100,101]$ did not confirm the presence of ${ }^{1} \mathrm{O}_{2}$ oxygen as suggested in the BAP system [29] containing sodium azide. The increase in degradation rate with azide was considered for production of two other reactive species $\left(\bullet \mathrm{N}_{3}\right.$ and $\bullet \mathrm{O}_{2}$ ) through Eqs. (30) and (31) because of their close rate constants for both $\bullet \mathrm{OH}$ and ${ }^{1} \mathrm{O}_{2}\left(1 \times 10^{10} \mathrm{vs} .2 \times 10^{9} \mathrm{~mol}^{-1} \mathrm{~L} \mathrm{~s}^{-1}\right)$ [106]. The existence of both $\bullet \mathrm{OH}$ and $\bullet \mathrm{O}_{2}{ }^{-}$was also confirmed by $\mathrm{Li}$ et al. [41] in a chemiluminescence study of the $\mathrm{H}_{2} \mathrm{O}_{2}-\mathrm{Co}^{2+}-\mathrm{NaHCO}_{3}$ system using ascorbic acid and SOD as scavengers. They also observed an increase in chemiluminescence intensity in response to the addition of $\mathrm{NaN}_{3}$. The authors attributed this increase to the formation of $\mathrm{NO}_{x}$ species that resulted from the reaction of $\mathrm{NaN}_{3}$ and $\bullet \mathrm{CO}_{3}{ }^{-}$radicals. The carbonate radicals produced through scavenging of $\bullet \mathrm{OH}$ Eq. (2) were also considered key reactive species in the BAP system during degradation of various pollutants $[29,100,101]$. The authors considered the importance of $\cdot \mathrm{CO}_{3}$ - radicals as ROS based on its activity in studies of different compounds such as pesticides, dyes, and even methyl $t$-butyl ether [107-109].

$$
\begin{aligned}
& \mathrm{H}_{2} \mathrm{O}_{2}+\bullet \mathrm{CO}_{3}-\rightarrow \mathrm{HCO}_{3}^{-}+\bullet \mathrm{OOH} \\
& \bullet \mathrm{OOH} \rightarrow \mathrm{H}^{+}+\bullet \mathrm{O}_{2} \\
& \bullet \mathrm{OH}+\bullet \mathrm{O}_{2} \rightarrow{ }^{1} \mathrm{O}_{2}+\mathrm{OH}^{-} \\
& \bullet \mathrm{OOH}+\bullet \mathrm{O}_{2} \rightarrow{ }^{1} \mathrm{O}_{2}+\mathrm{OOH}^{-} \\
& \bullet \mathrm{OOH}+\bullet \cdot \mathrm{OOH} \rightarrow \mathrm{1O}_{2}+\mathrm{H}_{2} \mathrm{O}_{2} \\
& -\mathrm{N}_{3}+{ }^{1} \mathrm{O}_{2} \rightarrow \bullet \mathrm{N}_{3}+\bullet \mathrm{O}_{2}- \\
& -\mathrm{N}_{3}+\bullet \mathrm{OH} \rightarrow \bullet \mathrm{N}_{3}+\mathrm{OH}^{-}
\end{aligned}
$$

As in previous studies, Duan et al. [102] assumed the presence of $\bullet \mathrm{OH}$ radical and $\bullet \mathrm{O}_{2}$ - during degradation of $\mathrm{AO}$. However, because of the important role of bicarbonate in the degradation of $\mathrm{AO}$, the authors assumed the schematic activation of $\mathrm{H}_{2} \mathrm{O}_{2}$, releasing both $\bullet \mathrm{OH}$ and $\bullet \mathrm{O}_{2}{ }^{-}$anion radicals on the catalyst surface as shown in Scheme 4 Eqs. (32)-(34).

\subsection{Application of bicarbonate in other advanced oxidation systems}

AOPs appear to be an important technology for wastewater 

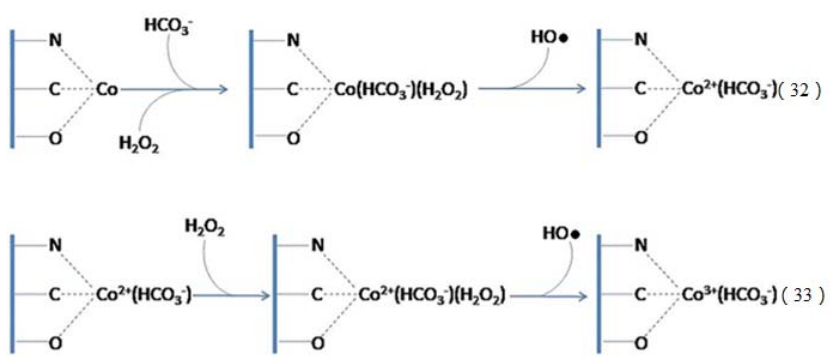

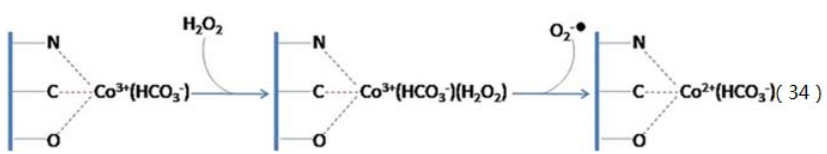

Scheme 4. Mechanism of $\mathrm{H}_{2} \mathrm{O}_{2}$ activation and $\mathrm{AO} 7$ degradation with $\mathrm{Co}_{x} \mathrm{O}_{y}-\mathrm{N} / \mathrm{GAC}$ in $\mathrm{HCO}_{3}{ }^{-}$solution. Reproduced from Ref. [102].

treatment because of their high efficiency at ambient conditions. However, all AOPs require application of certain oxidants such as $\mathrm{H}_{2} \mathrm{O}_{2}$, PMS, PS, or $\mathrm{O}_{3}$ to generate different ROS for degradation. The generation rate of these ROS can be improved by different methods including use of catalysts, light, etc., along with bicarbonate activation. All AOPs containing bicarbonates/carbonates were reported as scavengers of $\bullet \mathrm{OH}$ radicals [110]. However, the radical-radical recombination of bicarbonate radical $\left(1.2 \times 10^{7} \mathrm{~mol}^{-1} \mathrm{~L} \mathrm{~s}^{-1}\right)$ is considered much lower than that of $\bullet \mathrm{OH}$ radical $\left(5.5 \times 10^{9} \mathrm{~mol}^{-1} \mathrm{~L} \mathrm{~s}^{-1}\right)[29,110]$. Moreover, the carbonate radical generated from (eq. (2)) exists at much higher concentrations $\left(10^{-13}-10^{-15} \mathrm{~mol} / \mathrm{L}\right)$, about two order of magnitude higher than $\bullet \mathrm{OH}$ radical $\left(10^{-14}-10^{-18}\right.$ mol/L) in natural water, and was reported to be an active oxidant in many reactions $[39,46,106]$. Similarly, since its discovery in 1983, many studies have documented the role of bicarbonate as an activator of $\mathrm{H}_{2} \mathrm{O}_{2}$ [40-45]. More recently, the ability of bicarbonate to activate oxidants such as PS, $\mathrm{O}_{2}$ or $\mathrm{O}_{3}$ also attracted attention owing to its potential applications in wastewater [110-113]. For example, the $\mathrm{Mn}^{2+} / \mathrm{HCO}_{3}-/ \mathrm{O}_{3}$ system was reported to degrade atrazine, and influenced both degradation of atrazine and the residual $\mathrm{O}_{3}$ concentration as shown in Fig. 15 [110]. The slight increase in degradation of atrazine in this system was attributed to bicarbonate, which produces $\bullet \mathrm{CO}_{3}{ }^{-}$as a reactive species during degradation.

Dioxygen is the cleanest and most abundant oxidizing agent in nature, and its activation by different methods has been reported in wastewater treatment $[114,115]$. Li et al. reported a $\mathrm{Co}^{2+} / \mathrm{HCO}_{3}-/ \mathrm{O}_{2}$ system for degradation of 0 -aminophenol (OAP) as shown in Fig. 16 [112]. They found that $64.7 \%$ of OAP could be converted to the less harmful compound, 2-aminophenoxazine-3-one (APZ) in $90 \mathrm{~min}$, and this conversion increased to $92 \%$ after $240 \mathrm{~min}$. However, other transition metals such as $\mathrm{Mn}^{2+}, \mathrm{Fe}^{2+}$ and $\mathrm{Ni}^{2+}$ showed nearly no reactivity, while $\mathrm{Cu}^{2+}$ ions reacted four time slower than $\mathrm{Co}^{2+}$ ions.

Advanced oxidations based on peroxymonosulfate (PMS, $\mathrm{HSO}_{5}{ }^{-}$) or persulfate (PS, $\mathrm{S}_{2} \mathrm{O}_{8}{ }^{2-}$ ) recently emerged as efficient
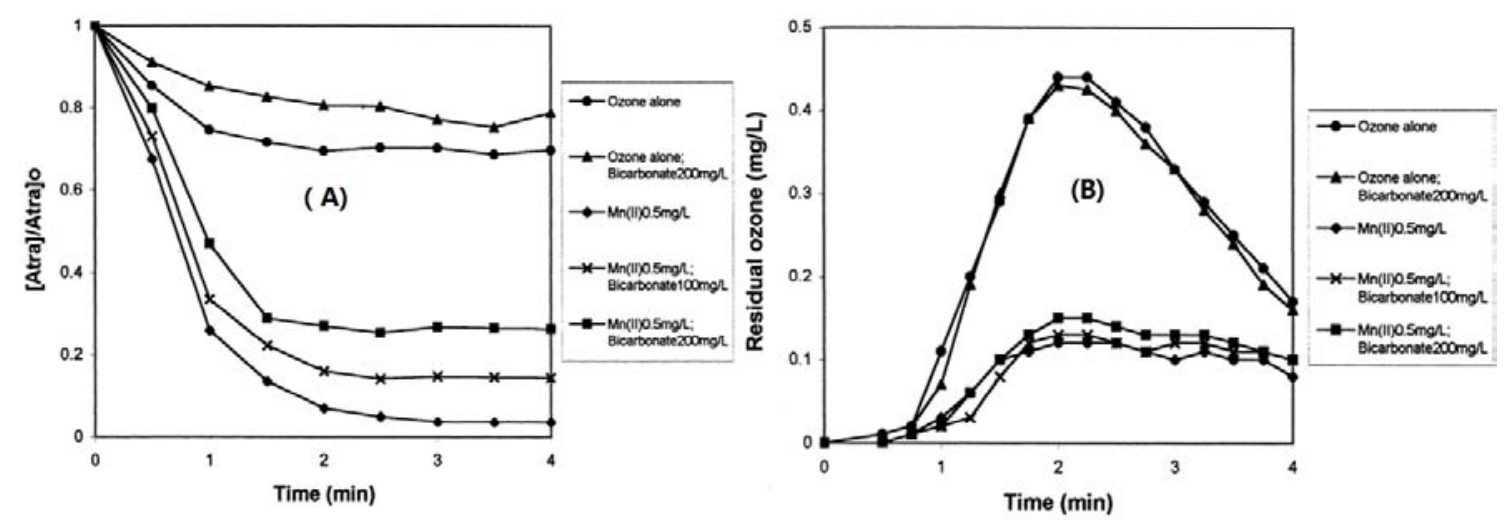

Fig. 15. (A) Effect of bicarbonate concentration on the degradation of atrazine. (B) Effect of bicarbonate concentration on residual ozone concentration. Conditions: $20^{\circ} \mathrm{C}$, pH $7.0\left(1 \mathrm{mmol} / \mathrm{L} \mathrm{PO}_{4}{ }^{3-}\right.$ buffer $)$, applied ozone $2.5 \mathrm{mg} / \mathrm{L}$. Reproduced from Ref. [110].

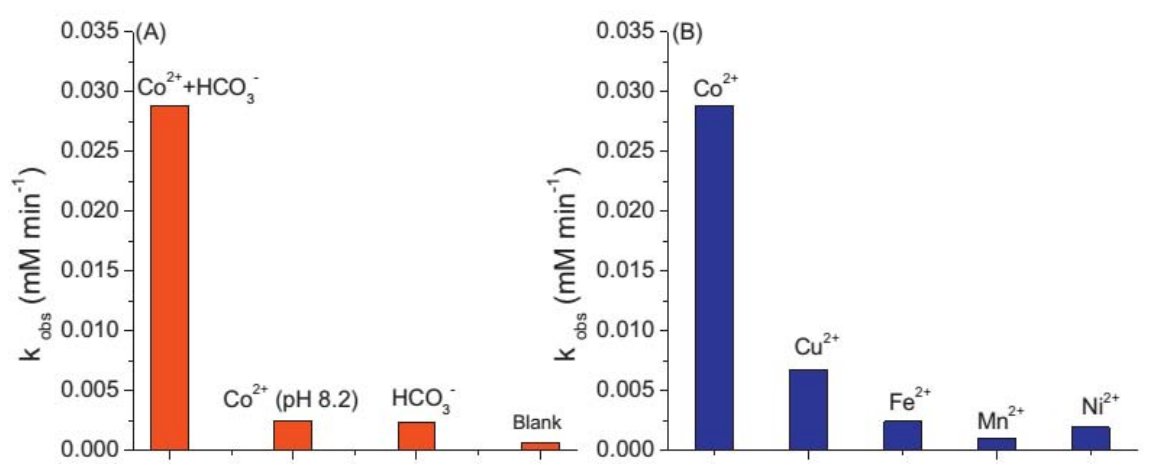

Fig. 16. (A) Effect of various reaction systems on the rate of APZ production. (B) Effect of different metal ions on the rate of APZ production. Conditions: metal ions $5 \mu \mathrm{mol} / \mathrm{L}, \mathrm{HCO}_{3}{ }^{-} 10 \mathrm{mmol} / \mathrm{L}, \mathrm{OAP} 0.367 \mathrm{mmol} / \mathrm{L}, 30^{\circ} \mathrm{C}$. Reproduced from Ref. [112]. 

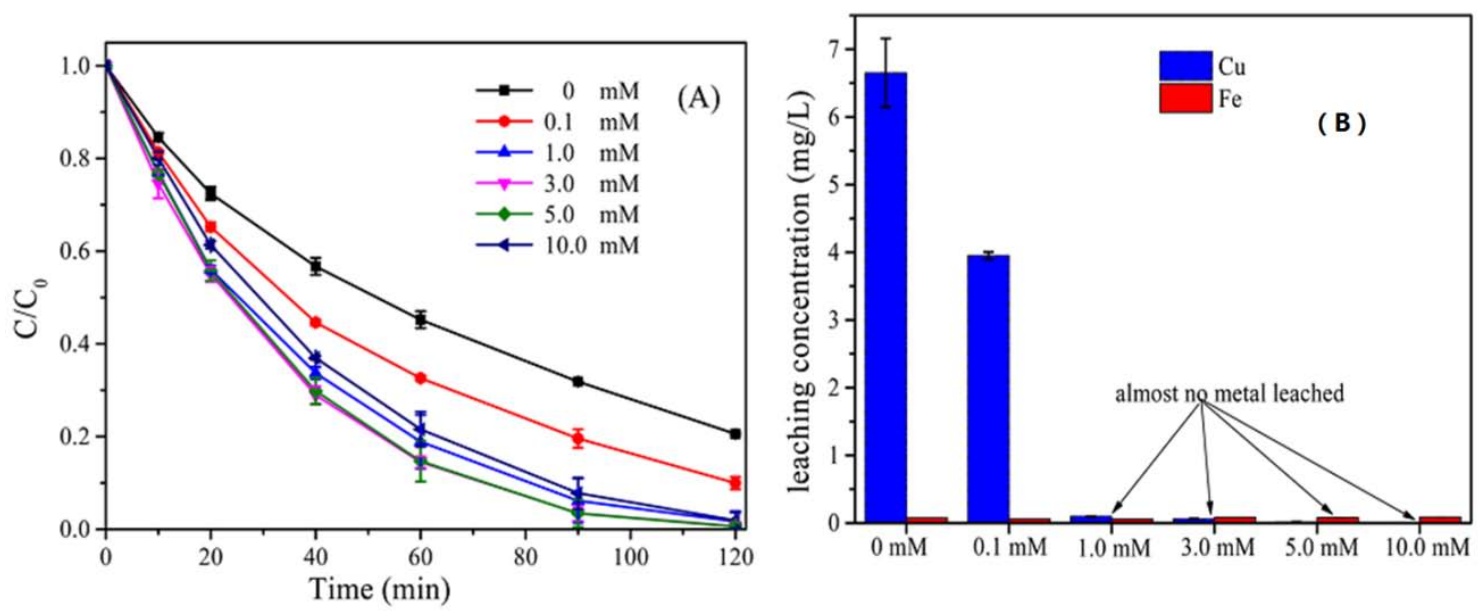

Fig. 17. (A) Influence of $\mathrm{NaHCO}_{3}$ concentration on the degradation of phenol in the $\mathrm{CuO}-\mathrm{Fe}_{3} \mathrm{O}_{4} / \mathrm{PS}$ system. (B) Metal leaching during the reaction in the $\mathrm{CuO}-\mathrm{Fe}_{3} \mathrm{O}_{4} / \mathrm{PS} / \mathrm{NaHCO}_{3}$ system. Conditions: PS $5 \mathrm{mmol} / \mathrm{L}$, phenol $0.1 \mathrm{mmol} / \mathrm{L}, \mathrm{CuO}-\mathrm{Fe}_{3} \mathrm{O}_{4} 0.3 \mathrm{~g} / \mathrm{L}$, time 120 min. Reproduced from Ref. [113].

technologies for degrading different kinds of organic pollutants $[113,116]$. For example, Lei et al. [113] reported the activation of PS with bicarbonate during phenol degradation, in which bicarbonate can increase both the efficiency and stability of the $\mathrm{CuO}-\mathrm{Fe}_{3} \mathrm{O}_{4}$ /PS system. As shown in Fig. 17, the degradation efficiency increased by nearly $18 \%$ with the addition of 10 $\mathrm{mmol} / \mathrm{L}$ bicarbonate. They also found that bicarbonate plays a role in minimizing catalyst leaching because of its buffer capacity $(\mathrm{pH} 8.0 \pm 0.5)$. For example, the leaching of $\mathrm{Cu}^{2+} \mathrm{de}-$ creased from $5.6 \mathrm{mg} / \mathrm{L}$ to less than $1.0 \mathrm{mg} / \mathrm{L}$ with the addition of $1 \mathrm{mmol} / \mathrm{L}$ bicarbonate. The leaching of $\mathrm{Cu}^{2+}$ decreased further as the bicarbonate concentration increased, and became negligible at $\geq 5 \mathrm{mmol} / \mathrm{L}$. The authors assumed that PS has a structure similar to $\mathrm{H}_{2} \mathrm{O}_{2}$, and could therefore react in a similar fashion as bicarbonate Eq. (35) to produce $\mathrm{HCO}_{4}^{-}$anion, which may further accelerate the oxidation of $\mathrm{Cu}^{2+}$ to $\mathrm{Cu}^{3+}$.

$$
\mathrm{HCO}_{3}^{-}+\mathrm{S}_{2} \mathrm{O}_{8}^{2-} \rightarrow \mathrm{HCO}_{4}^{-}+\mathrm{SO}_{4}^{-}+\mathrm{SO}_{3}^{-}
$$

\section{Perspectives}

This review summarized recent progress in utilizing bicarbonate to activate $\mathrm{H}_{2} \mathrm{O}_{2}$ for pollutant degradation. The merit of the BAP system is its buffer $\mathrm{pH}$ (around neutral or weakly alkaline) throughout the wastewater treatment process, which makes the heterogeneous catalysts more resistant to leaching and thus more stable with time. The formation of $\mathrm{HCO}_{4}^{-}$and - $\mathrm{CO}_{3}{ }^{-}$oxidants are additional merits of this system. The data reviewed here also highlighted the promotion effect of bicarbonate in $\mathrm{H}_{2} \mathrm{O}_{2}$ based pollutant degradation, whereas it was previously regarded as a drawback to wastewater treatment. Although many studies have been conducted to address the use of ROS for degradation, it seems that ROS are catalyst dependent in different systems. Accordingly, more detailed investigations are still needed to address the mechanisms for degradation. It should also be noted that bicarbonate has been gradually applied in $\mathrm{H}_{2} \mathrm{O}_{2}$ based AOPs, as well as in other advanced oxidation systems such as those using PS, $\mathrm{O}_{2}$ and $\mathrm{O}_{3}$ as oxidants, which will offer more attractive applications of bicarbonate for pollutant degradation.

\section{References}

[1] N. Bolong, A. F. Ismail, M. R. Salim, T. Matsuura, Desalination, 2009, 239, 229-246.

[2] K. E. Murray, S. M. Thomas, A. A. Bodour, Environ. Pollut,, 2010, 158, 3462-3471.

[3] R. Rosal, A. Rodríguez, J. A. Perdigón-Melón, A. Petre, E. García-Calvo, M. J. Gómez, A. Agüera, A. R. Fernández-Alba, Water Res., 2010, 44, 578-588.

[4] S. D. Richardson, T. A. Ternes, Anal. Chem., 2011, 83, 4614-4648.

[5] D. J. Lapworth, N. Baran, M. E. Stuart, R. S. Ward, Environ. Pollut., 2012, 163, 287-303.

[6] N. Ratola, A. Cincinelli, A. Alves, A. Katsoyiannis, J. Hazard. Mater., 2012, 239-240, 1-18.

[7] A. D. Bokare, W. Choi, J. Hazard. Mater., 2014, 275, 121-135.

[8] V. L. Tyagi, S. L. Lo, Environ. Sci. Biotechnol, 2011, 10, 215-242.

[9] E. Neyens, J. Baeyens, J. Hazard. Mater., 2003, 98, 33-50.

[10] K. Ranganathan, K. Karunagaran, D. C. Sharma, Resour. Conserv. Recycling., 2007, 50, 306-318.

[11] I. Arslan-Alaton, I. Alaton, Ecotox. Environ. Safe., 2007, 68, 98-107.

[12] C. Catrinescu, C. Teodosiu, M. Macoveanu, J. Miehe-Brendle, R. Le Dred, Water Res., 2003, 37, 1154-1160.

[13] J. A. Melero, F. Martínez, J. A. Botas, R. Molina, M. I. Pariente, Water Res., 2009, 43, 4010-4018.

[14] R. J. Watts, J. Sarasa, F. J. Loge, A. L. Teel, J. Environ. Eng., 2005, 131, 158-164.

[15] J. Madhavan, P. Maruthamuthu, S. Murugesan, M. Ashokkumar, Appl. Catal. A, 2009, 368, 35-39.

[16] Y. F. Han, F. X. Chen, Z. Y. Zhong, K. Ramesh, L. W. Chen, D. Jian, W. W. Ling, Chem. Eng. J., 2007, 134, 276-281.

[17] J. K. Kim, I. S. Metcalfe, Chemosphere, 2007, 69, 689-696.

[18] I. A. Salem, M. S. El-Maazawi, Chemosphere, 2000, 41, 1173-1180.

[19] S. Chaliha, K. G. Bhattacharyya, J. Hazard. Mater., 2008, 150, 728-736.

[20] S. Navalon, M. Alvaro, H. Garcia, Appl. Catal. B, 2010, 99, 1-26.

[21] M. Hartmann, S. Kullmann, H. Keller, J. Mater. Chem., 2010, 20, 9002-9017.

[22] R. M. Liou, S. H. Chen, J. Hazard. Mater., 2009, 172, 498-506.

[23] K. M. Valkaj, A. Katovic, S. Zrnčević, J. Hazard. Mater., 2007, 144, 663-667.

[24] O. P. Pestunova, O. L. Ogorodnikova, V. N. Parmon, Chem. Sustain. 
Develop., 2003, 11, 227-232.

[25] J. Barrault, C. Bouchoule, K. Echachoui, N. Frini-Srasra, M. Trabelsi, F. Bergaya, Appl. Catal. B, 1998, 15, 269-274.

[26] T. Granato, A. Katovic, K. Maduna Valkaj, A. Tagarelli, G. Giordano, J. Porous Mater., 2009, 16, 227-232.

[27] S. Zrnčevic, Z. Gomzi, Ind. Eng. Chem. Res., 2005, 44, 6110-6114.

[28] S. Muhammad, E. Saputra, H. Q. Sun, H. M. Ang, M. O. Tadé, S. B. Wang, Ind. Eng. Chem. Res., 2002, 51, 15351-15359.

[29] L. Zhou, W. Song, Z. Q. Chen, G. C. Yin, Environ. Sci. Technol., 2013, 47, 3833-3839.

[30] D. B. Medinas, G. Cerchiaro, D. F. Trindade, O. Augusto, IUBMB life, 2007, 59, 255-262.

[31] D. C. Ramirez, S. E. Mejiba, R. P. Mason, J. Biol. Chem., 2005, 280, 27402-27411.

[32] K. N. Ferreira, T. M. Iverson, K. Maghlaoui, J. Barber, S. Iwata, Science, 2004, 303, 1831-1838.

[33] V. V. Klimov, S. V. Baranov, Biochim. Biophys. Acta, 2001, 1503, 187-196.

[34] H. Yao D. E. Richardson, J. Am. Chem. Soc., 2000, 122, 3220-3221.

[35] D. A. Bennett, H. Yao, D. E. Richardson, Inorg. Chem., 2001, 40, 2996-3001.

[36] B. Balagam, D. E. Richardson, Inorg. Chem., 2008, 47, 1173-1178.

[37] D. E. Richardson, C. A. S. Regino, H. R. Yao, J. V. Johnson, Free Radical Biol. Med., 2003, 35, 1538-1550.

[38] S. Sankarapandi, J. L. Zweier, J. Biol. Chem., 1999, 274, 1226-1232.

[39] O. Augusto, M. G. Bonini, A. M. Amanso, E. Linares, C. C. Santos, S. L. De Menezes, Free Radical. Biol. Med., 2002, 32, 841-859.

[40] S. Canonica, T. Kohn, M. Mac, F. J. Real, J. Wirz, U. V. Gunten, Environ. Sci. Technol., 2005, 39, 9182-9188.

[41] J. G. Li, Q. Q. Li, C. Lu, L. X. Zhao, J. M. Lin, Spectrochim. Acta A, 2011, 78A, 700-705.

[42] K. Staninski, M. Kaczmarek, M. Elbanowski, J. Alloys Compds., 2004, 380, 177-180.

[43] S. C. Zhang, Y. Y. Wu, H. Li, Talanta, 2000, 53, 609-616.

[44] K. S. Haygarth, T. W. Marin, I. Janik, K. Kanjana, C. M. Stanisky, D. M. Bartels, J. Phy. Chem. A, 2010, 114, 2142-2150.

[45] M. Viisimaa A. Goi, J. Environ. Eng. Landsc. Manag., 2014, 22, 30-39.

[46] C. L. Wu, K. G. Linden, Water Res., 2010, 44, 3585-3594.

[47] C. A. S. Regino, D. E. Richardson, Inorg. Chim. Acta., 2007, 360, 3971-3977.

[48] S. Caudo, G. Centi, C. Genovese, S. Perathoner, Top. Catal., 2006, 40, 207-219.

[49] M. S. Lucas, J. A. Peres, J. Hazard. Mater., 2009, 168, 1253-1259.

[50] J. M. Monteagudo, A. Durán, C. López-Almodóvar, App. Catal. B, 2008, 83, 46-55.

[51] A. H. Xu, H. Xiong, G. C. Yin, J. Phys. Chem. A, 2009, 113, 12243-12248.

[52] E. Ember, H. A. Gazzaz, S. Rothbart, R. Puchta, R. Van Eldik, Appl. Catal. B, 2010, 95, 179-191.

[53] S. B. Wang, Dyes Pigments, 2008, 76, 714-720.

[54] A. Sorokin, S. De Suzzoni-Dezard, D. Poullain, J. P. Noel, B. Meunier, J. Am. Chem. Soc., 1996, 118, 7410-7411.

[55] X. Tao, W. H. Ma, T. Y. Zhang, J. C. Zhao, Angew. Chem. Int. Ed., 2001, 40, 3014-3016.

[56] R. Su, J. Sun, Y. P. Sun, K. J. Deng, D. M. Cha, D. Y. Wang, Chemosphere, 2009, 77, 1146-1151.

[57] A. Theodoridis, J. Maigut, R. Puchta, E. V. Kudrik, R. Van Eldik, Inorg. Chem., 2008, 47, 2994-3013.

[58] K. M. Thompson, W. P. Griffith, M. Spiro, J. Chem. Soc., Chem. Commun., 1992, 1600-1601.

[59] G. W. Wagner, Y. C. Yang, in: Proceedings of the ERDEC Scientific
Conference on Chemical and Biological Defense Research, US Army Edgewood Chemical Biological Center, 1999.

[60] S. Caudo, G. Centi, C. Genovese, S. Perathoner, Top. Catal., 2006., 40, 207-219.

[61] P. Bautista, A. F. Mohedano, M. A. Gilarranz, J. A. Casas, J. J. Rodriguez, J. Hazard. Mater., 2007, 143, 128-134.

[62] F. Magalhaes, M. C. Pereira, S. E. C. Botrel, J. D. Fabris, W. A. Macedo, R. Mendonca, R. M. Lago, L. C. A. Oliveira, Appl. Catal. A, 2007, 332, 115-123.

[63] H. R.Tetzlaff, J. H. Espenson, Inorg. Chem., 1999, 38, 881-885.

[64] D. E. De Vos, B. F. Sels, M. Reynaers, Y. V. S. Rao, P. A. Jacobs, Tetrahedron Let., 1998, 39, 3221-3224.

[65] H. J. Dutton, Prog. Chem. Fats Lipids, 1971, 9, 349-375.

[66] G. B. Payne, J. Org. Chem., 1961, 26, 663-668.

[67] R. Drago, K. Frank Y. C. Yang, in: Proceedings of the ERDEC Scientific Conference on Chemical and Biological Defense Research, US Army Edgewood Research, Aberdeen Proving Ground, MD, 1998.

[68] A. H. Xu, X. X. Li, H. Xiong, G. C. Yin, Chemosphere, 2011, 82, 1190-1195.

[69] A. Sorokin, J. L. Séris, B. Meunier Science, 1995, 268, 1163-1166.

[70] Y. P. Huang, W. H. Ma, J. Li, M. M. Cheng, J. C. Zhao, L. J. Wan, J. C. Yu, J. Phy. Chem. B, 2003, 107, 9409-9414.

[71] C. Tai, G. B. Jiang, Chemosphere, 2005, 59, 321-326.

[72] S. Caudo, G. Centi, C. Genovese, S. Perathoner, Top. Catal., 2006, 40, 207-219.

[73] D. B. Medinas, J. C. Toledo, G. Cerchiaro, A. T. Do-amaral, L. De-Rezende, A. Malvezzi, 0. Augusto, Chem. Res. Toxicol., 2009, 22, 639-648.

[74] A. H. Xu, K. J. Shao, W. L. Wu, J. Fan, J. J. Cui, G. C. Yin, Chin. J. Catal., 2010, 31, 1031-1036.

[75] E. Ember, S. Rothbart, R. Puchta, R. Van Eldik, New J. Chem., 2009, 33, 34-49.

[76] E. Ember, H. A. Gazzaz, S. Rothbart, R. Puchta, R. Van Eldik, Appl. Catal. B, 2010, 95, 179-191

[77] E. R. Stadtman, B. S. Berlett, P. B. Chock, Proc. Natl. Acad. Sci. USA, 1990, 87, 384-388.

[78] B. S. Berlett, P. B. Chock, M. B. Yim, E. R. Stadtman, Proc. Natl. Acad. Sci. USA, 1990, 87, 389-393.

[79] M. B. Yim, B. S. Berlett, P. B. Chock, E. R. Stadtman, Proc. Natl. Acad. Sci. USA, 1990, 87, 394-398.

[80] E. K. Hodgson, I. Fridovich, Biochemistry, 1975, 14, 5299-5303.

[81] S. Sankarapandi, J. L. Zweier, J. Biol. Chem., 1999, 274, 1226-1232.

[82] S. I. Liochev, I. Fridovich, Free Radical Biol. Med., 1999, 27, 1444-1447.

[83] H. Zhang, J. Joseph, C. Felix, B. Kalyanaraman, J. Biol. Chem., 2000, 275,14038-14045.

[84] H. Zhang, J. Joseph, M. Gurney, D. Becker, B. Kalyanaraman, J. Biol. Chem., 2002, 277, 1013-1020.

[85] H. Zhang, C. Andrekopoulos, J. Joseph, K. Chandran, H. Karoui, J. P. Crow, B. Kalyanaraman, J. Biol. Chem., 2003, 278, 24078-24089.

[86] S. I. Liochev, I. Fridovich, J. Biol. Chem., 2002, 277, 34674-34678.

[87] S. I. Liochev, I. Fridovich, Proc. Natl. Acad. Sci. USA, 2004, 101, 743-744

[88] S. I. Liochev, I. Fridovich, Proc. Natl. Acad. Sci. USA, 2004, 101, 12485-12490.

[89] M. V. Kirillova, Y. N. Kozlov, L. S. Shulpina, O. Y. Lyakin, A. M. Kirillov, E. P. Talsi, A. J. L. Pombeiro, G. B. Shul'pin, J. Catal., 2009, 268, 26-38.

[90] A. Conde, L. Vilella, D. Balcells, M. M. Díaz-Requejo, A. Lledos,'P. J. Perez, J. Am. Chem. Soc., 2013, 135, 3887-3896.

[91] V. Shah, P. Verma, P. Stopka, J. Gabriel, P. Baldrian, F. Nerud, Appl. 


\title{
Graphical Abstract
}

Chin. J. Catal., 2016, 37: 810-825 doi: 10.1016/S1872-2067(15)61100-7

Bicarbonate activation of hydrogen peroxide: A new emerging technology for wastewater treatment

Ali Jawad, Zhuqi Chen, Guochuan Yin*

Huazhong University of Science and Technology

Catalytic treatment based on BAP systems appears to be a promising technology for wastewater treatment that offers several benefits including being eco-friendly, highly efficient having increased process stability.

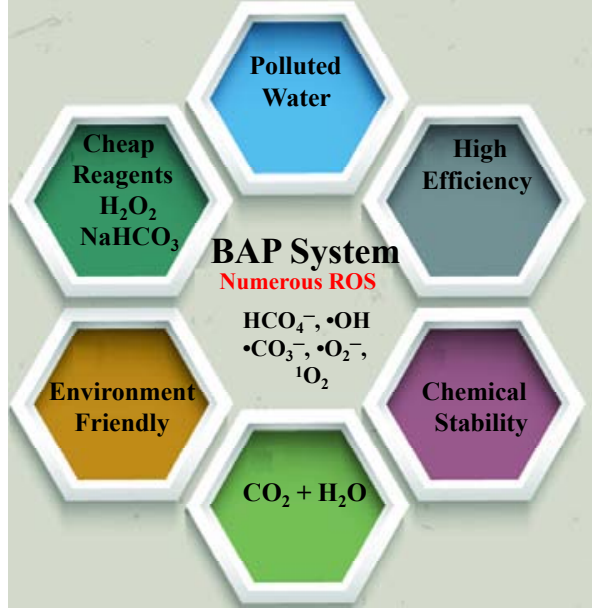

Catal. B, 2003, 46, 287-292.

[92] Y. Li, Z. Z. Yi, J. C. Zhang, M. Z. Wu, W. Liu, P. Q. Duan, J. Hazard. Mater., 2009, 171, 1172-1174.

[93] L. Cheng, M. Y. Wei, L. H. Huang, F. Pan, D. S. Xia, X. X. Li, A. H. Xu, Ind. Eng. Chem. Res., 2014, 53, 3478-3485.

[94] H. S. Lee, H. J. Lee, D. L. Sedlak, C. Lee, Chemosphere, 2013, 92, 652-658.

[95] A. H. Xu, X. X. Li, S. Ye, G. C. Yin, Q. F. Zeng, Appl. Catal. B, 2011, $102,37-43$

[96] M. X. Luo, L. P. Lv, G. W. Deng, W. Yao, Y. Ruan, X. X. Li, A. H. Xu, Appl. Catal. A, 2014, 469, 198-205.

[97] X. X. Li, Z. D. Xiong, X. C. Ruan, D. S. Xia, Q. F. Zeng, A. H. Xu, Appl. Catal. A, 2012, 411, 24-30.

[98] Z. Yang, H. Wang, M. Chen, M. X. Luo, D. S. Xia, A. H. Xu, Q. F. Zeng,. Ind. Eng. Chem. Res., 2012, 51, 11104-11111.

[99] X. J. Long, Z. Yang, H. Wang, M. Chen, K. Y. Peng, Q. F. Zeng, A. H. $\mathrm{Xu}$, Ind. Eng. Chem. Res., 2012, 51, 11998-12003.

[100] A. Jawad, X. Y. Lu, Z. Q. Chen, G. C. Yin, J. Phys. Chem. A, 2014, 118, 10028-10035.

[101] A. Jawad, Y. B. Li, X. Y. Lu, Z. Q. Chen, W. D. Liu, G. C. Yin, J. Hazard. Mater., 2015, 289, 165-173.

[102] L. Duan, Y. L. Chen, K. X. Zhang, H. Y. Luo, J. X. Huang, A. H. Xu, RSC Adv., 2015, 5, 84303-84310.

[103] A. Caballero, J. P. Holgado, V. M. Gonzalez-delaCruz, S. E. Habas, T. Herranz, M. Salmeron, Chem. Commun., 2010, 46, 1097-1099.
[104] L. H. Zhang, F. Li, D. G. Evans, X. Duan, Mater. Chem. Phys., 2004, 87, 402-410.

[105] C. L. Hawkins, M. J. Davies, Biochim. Biophys. Acta Gen. Subj., 2014, 1840, 708-721.

[106] Z. B. Alfassi, R. H. Schuler, J. Phys. Chem., 1985, 89, 3359-3363.

[107] J. Huang, S. A. Mabury, Environ. Toxicol. Chem., 2000, 9 , 1501-1507.

[108] H. M. Hung, J. W. Kang, M. R. Hoffmann, Water Environ. Res., 2002, 74, 545-556.

[109] C. Minero, P. Pellizzari, V. Maurino, E. Pelizzetti, D. Vione, Appl. Catal. B, 2008, 77, 308-316.

[110] J. Ma, N. J. D. Graham, Water Res., 2000, 34, 3822-3828.

[111] J. L. Acero V. Gunten, in: Proceedings of Ozonation and AOPs in Water Treatment, France, 1998, 13.

[112] X. X. Li, W. Shi, Q. Cheng, L. H. Huang, M. Y. Wei, L. Cheng, A. H. Xu, Appl. Catal. A, 2014, 475, 297-304.

[113] Y. Lei, C. S. Chen, Y. J. Tu, Y. H. Huang, H. Zhang, Environ. Sci. Technol, 2015, 49, 6838-6845.

[114] Z. H. Ai, Z. T. Gao, L. Z. Zhang, W. W. He, J. J. Yin, Environ. Sci. Technol., 2013, 47, 5344-5352.

[115] C. Noradoun, M. D. Engelmann, M. McLaughlin, R. Hutcheson, K. Breen, A. Paszczynski, I. F. Cheng, Ind. Eng. Chem. Res., 2003, 42, 5024-5030.

[116] X. G. Duan, H. Q. Sun, Y. X. Wang, J. Kang, S. B. Wang, ACS Catal., 2014, 5, 553-559.

\section{碳酸氢盐活化的过氧化氢: 一种有机废水处理的新技术}

\author{
Ali Jawad，陈朱琦，尹国川 \\ 华中科技大学化学与化工学院，湖北省材料化学与服役失效重点实验室，湖北武汉430074
}

摘要: 水污染问题已成为影响我国可持续发展的关键问题之一, 为有效提高现有污水处理的效率及其回收利用, 各种催化 氧化技术受到了广泛的关注. 目前发展的各类高级氧化技术在实际的应用过程中明显受到了氧化剂的利用率、催化剂的 浸出、寿命及成本等问题的严重限制. 因此基于新的理念、发展新的催化氧化技术仍然受到广泛的关注.

最近几年, 利用碳酸氢盐活化过氧化氢, 应用于有机废水的降解逐渐受到环境催化领域的关注. 碳酸氢盐本身是一种 低毒性、广泛存在于环境及生物体系的化学物质, 通过它活化过氧化氢产生过碳酸氢盐氧化剂, 该氧化剂能够直接氧化有 机物. 同时,在各种过渡金属催化剂的存在下,通过该过碳酸氢盐可以形成氧化能力更强的各种自由基 (如羟基自由基等) 
及高价态的过渡金属离子参与有机废水的降解. 虽然传统认为碳酸盐及碳酸氢盐对高级氧化法降解有机废水不利, 原因 是认为它们能捕捉羟基自由基, 形成氧化能力更低的碳酸根自由基. 现有的研究已充分表明, 较低浓度的碳酸氢盐能够加 快有机废水的氧化降解, 而且通常比单独使用过氧化氢效率更高, 这些新的发现已明显突破了传统意义上对碳酸氢盐作用 的理解. 更为重要的是, 在微量碳酸氢盐的存在下, 其产生的微碱性环境极大地消除了负载型氧化物催化剂在废水降解过 程中的金属离子流失、从而极大地延长了催化剂的寿命. 该缺点是各种基于过渡金属氧化物催化剂的高级氧化技术难以 广泛推广的关键性挑战, 原因是随着氧化降解的进行, 废水体系由于有机酸的生成而逐渐酸化, 进而引发氧化物催化剂的 酸溶而流失. 在这点上, 碳酸氢盐活化过氧化氢系统由于其天然的微碱性环境体现出了其明显的优势.

本文即是在本课题组工作基础上, 对该领域内国内外研究进展加以总结, 以期获得国内外同行的进一步关注. 综述的 主要内容包括: (1) 碳酸氢氧活化过氧化氢的相关知识介绍, (2) 均相碳酸氢氧活化过氧化氢降解有机废水的研究进展, (3) 基于金属氧化物催化剂的碳酸氢氧活化过氧化氢降解有机废水的研究进展, 和 (4) 碳酸氢盐在其他高级氧化技术中的应 用. 虽然基于碳酸氢氧活化过氧化氢降解有机废水的研究还处于早期探索阶段, 还有很多基础科学问题如降解机理等值 得进一步探索, 期望通过该综述的介绍能够让同行对碳酸氢氧活化过氧化氢降解有机废水有一个比较全面的了解, 进而推 动该研究方向的发展, 为有机废水的催化处理提供新的机会.

关键词: 废水处理; 碳酸氢盐活化过氧化氢; 催化剂浸出; 污染降解; 催化氧化

收稿日期: 2016-02-29. 接受日期: 2016-03-31. 出版日期: 2016-06-05.

*通讯联系人. 电话: (027)87543032; 传真: (027)87543632; 电子信箱: gyin@hust.edu.cn

基金来源：国家自然科学基金 (21273086).

本文的英文电子版由Elsevier出版社在ScienceDirect上出版(http://www.sciencedirect.com/science/journal/18722067). 